\title{
Modulation of human mesenchymal and pluripotent stem cell behaviour using biophysical and biochemical cues: a review ${ }^{\dagger}$
}

Sheryl Ding, ${ }^{1}$ Peter Kingshott, ${ }^{1}$ Helmut Thissen, ${ }^{2}$ Martin Pera, ${ }^{3}$ Peng-Yuan Wang ${ }^{1,2,3 *}$

1 Department of Chemistry and Biotechnology, Swinburne University of Technology, Hawthorn, 3122 Victoria, Australia

2 CSIRO Manufacturing, Bayview Avenue, Clayton, 3168 Victoria, Australia

3 Department of Anatomy and Neuroscience, Walter and Eliza Hall Institute of Medical Research, Florey Neuroscience and Mental Health Institute, The University of Melbourne, 3010 Victoria, Australia

*Corresponding author: Dr. Peng-Yuan Wang; Tel: +61 3 92145939; email:

pengyuanwang@swin.edu.au

\footnotetext{
$\dagger$ This article has been accepted for publication and undergone full peer review but has not been through the copyediting, typesetting, pagination and proofreading process, which may lead to differences between this version and the Version of Record. Please cite this article as doi: [10.1002/bit.26075]
}

Additional Supporting Information may be found in the online version of this article. 


\section{Abstract}

In vitro manipulation of human stem cells is a critical process in regenerative medicine and cellular therapies. Strategies and methods to maintain stem cells and direct them into specific lineages are ongoing challenges in these fields. To date, a number of studies have reported that besides biochemical stimulation, biophysical cues in the form of surface patterning and external stimulation also influence stem cell attachment, proliferation and differentiation, and can be used in cell reprogramming and the maintenance of pluripotency. While biochemical cues generally are effective and easy to deliver, biophysical cues have many other advantages for scalability as they are cost-efficient, have a longer lifetime, and can be easily well-defined. However, different protocols and cell sources utilized in a variety of studies have led to difficulties in obtaining clear conclusions about the effects of the biophysical environment on stem cells. In addition, the examination of different types of external stimulation is time consuming and limited by available fabrication techniques, resulting in a delay in commercialisation and clinical applications. In this review, we aim to summarise the most important biophysical cues and methods for the culture of human stem cells, including mesenchymal and pluripotent stem cells, to facilitate their adoption in stem cell biology. The standard classical protocols of using biochemical cues will also be discussed for comparison. We believe that combining biochemical and biophysical stimulation has the greatest potential to generate functionally mature cells at a scalable and inexpensive rate for diverse applications in regenerative medicine and cell therapy.

Keywords: human stem cells, biophysical stimulation, differentiation, cell reprogramming, tissue engineeringOutline

\section{Introduction}

2. Biophysical stimulation 


\subsection{Surface topography}

\subsection{Substrate stiffness}

2.3. Compression and stretching

2.4. Electric or magnetic fields

2.5. Ultrasound stimulation, photostimulation, and combined biophysical cues

3. Biochemical stimulation

3.1. Soluble factors in media

3.2. Surface-immobilised biosignals

4. Combining chemical and physical stimulation

5. Conclusion and future prospects

\section{Introduction}

Stem cells have the ability to self-renew indefinitely and differentiate into other cell types (Kosovsky, 2013), offering numerous potential applications in regenerative medicine and as research models (de Peppo and Marolt, 2013; Porcellini, 2009). Developing methods to expand stem cells, maintain their phenotype, and direct cell lineage differentiation with artificial materials is a vital step towards realising this potential (de Peppo and Marolt, 2013).

Pluripotent stem cells (PSCs) include embryonic stem cells (ESCs) and induced pluripotent stem cells (iPSCs). PSCs have the ability to differentiate into cells of any of the three germ layer lineages - ectoderm, mesoderm and endoderm - using chemical and/or biochemical methods (Efthymiou et al., 2014), and have immense potential in cell therapy, drug screening 
and disease modelling (Hazeltine et al., 2013; Kingham and Oreffo, 2013). ESCs are derived from the early embryo, while iPSCs are adult somatic cells artificially reprogrammed to become pluripotent and self-renewing (Takahashi and Yamanaka, 2006). Some differences do exist between ESCs and iPSCs, such as the presence of epigenetic "memory" in iPSCs (Kosovsky, 2013), but in general, they are extremely similar (Kingham and Oreffo, 2013). There are fewer ethical issues concerning iPSCs compared to ESCs, and they could revolutionise regenerative medicine with the possibility of patient-specific treatments (Kingham and Oreffo, 2013). Overall, PSCs have a promising future in research and medicine owing to their unique properties.

Multipotent stem cells, such as mesenchymal stem cells (MSCs) derived from bone marrow or adipose tissue, have a more restricted differentiation ability compared to PSCs. However, they are easier to harvest and expand without ethical issues around their provenance. MSCs derived from mesodermal tissues can spontaneously differentiate or be directed to differentiate into mesodermal cells like osteoblasts, chondrocytes, or adipocytes (Cook and Genever, 2013). Though still a controversial finding, it has been reported that in addition to these mesoderm lineages, MSCs can be transdifferentiated into nerve cells, hepatocytes, betapancreatic islets and certain epithelial cell types using specific induction media (Damien and Allan, 2015; Porcellini, 2009). Therefore, it appears that biochemical stimulation in the form of induction media can essentially break the barriers between cell lineages (Cho et al., 2012; Thrivikraman et al., 2014), although many uncertainties still exist about this method, such as the underlying cellular signalling pathways involved (Wang et al., 2016c). Nevertheless, MSCs can vary depending on their tissue of origin (Damien and Allan, 2015), and the source of cells must be considered in clinical use to ensure safety and efficacy (Hoogduijn et al., 2014). MSCs have also been found to modulate the behaviour of other cells such as neural stem cells through paracrine signalling, with important implications for the clinical uses of 
MSCs (Haragopal et al., 2015; Yang et al., 2015). Multipotent stem cells may have some limitations compared to pluripotent stem cells, but research into these cells still has great potential.

While biochemical modulation of stem cell growth and differentiation using small molecules and growth factors have been the focus of stem cell biology for years (Efthymiou et al., 2014), less attention has been paid to biophysical cues but recent research is proving to be very promising (Downing et al., 2013; Hao et al., 2015; Kshitiz et al., 2012; Wang and Tsai, 2015). Studies have proposed that biophysical cues can direct stem cell behaviour by either maintaining their phenotype or improving lineage commitment, and they are of great interest because they are cost-effective, longer-lasting, easily characterised and can be manufactured with high reproducibility (Villa-Diaz et al., 2013). However, limited fabrication techniques, which present problems with scale up and fabrication of large scale substrates for systematic studies, have led to a delay in clinical or industrial applications of these technologies. On the other hand, biochemical modulation (e.g. adding different growth factors to culture media) are easy to handle but expensive and difficult to control or define over the long term, because the functional half-life of biochemical factors is generally short and varies depending on the molecule (Johnson et al., 2015; Lee and Blaber, 2009; Mitchell et al., 2016). The majority of studies nowadays is using static culture where the period of medium change and diffusion of growth factors are varying between laboratories. Uncertainties in using these biomolecule approaches, such as safety issues, still exist. Methods of biochemical and biophysical manipulation of stem cells each have their advantages and disadvantages.

This review explores what is currently known about biophysical manipulation of stem cells, and how it compares to biochemical methods, and how the combination of both methods could provide advantages compared to established biochemical methods alone. 
Differentiation and maintenance of the multi- or pluripotency of stem cells will be the focus of this review. An overall summary of topics covered are presented in Illustration 1.

Illustration 1. A summary of various strategies to control human stem cell expansion and differentiation. Culture media and substrates are both critical for stem cell manipulation including cellular reprogramming, lineage reprogramming, expansion, differentiation. While biochemical methods are easy to handle but hard to control over the long term, biophysical methods are harder to handle but can be easily characterised and controlled. Stem cells must be cultured under a fully defined system before using in clinic. A combinational protocol of biochemical and biophysical cues may be needed for the effective generation of functionally mature adult cells.

\section{Biophysical stimulation}

The effects of a wide variety of biophysical cues on stem cell culture have been extensively investigated by many groups (Cha et al., 2013; Dalby et al., 2007; Engler et al., 2008; Geuss and Suggs, 2013; Hirt et al., 2014; Lee et al., 2010; Li et al., 2015; McMurray et al., 2011; Rao et al., 2013; Sridharan et al., 2009; Tandon et al., 2009; Wang et al., 2011; Wang et al., 2015d; Wittenbrink et al., 2015). Biophysical cues known to have an effect on stem cell behaviour include substrate patterning (Downing et al., 2013; Villa-Diaz et al., 2013), matrix stiffness (Engler et al., 2006), external stress and strain (Hazeltine et al., 2013; Nava et al., 2012), electrical stimulation (Chan et al., 2013), hydrostatic pressure (Nava et al., 2012), electromagnetic fields (Kim et al., 2015), ultrasound (Kang et al., 2013a), and photostimulation (Wilner, 2010). However, the effects of individual types of biophysical 
stimulation have not yet been completely elucidated. It is important to note that many outcomes reported using biophysical perspectives have also been based on combinational protocols which contain both biophysical and biochemical cues (e.g. soluble molecules in culture media). The true biophysical effects on stem cell culture in the absence of any additional chemical factors is an issue in stem cell culture that needs clarifying. In this section, we discuss the effects of biophysical effects in terms of surface topography (particularly at the submicron scale), substrate stiffness, and external forces on stem cell culture, as listed in Table $\mathbf{1 .}$

Many systems have been developed to biophysically stimulate cells during in vitro culture. Several methods are available for producing various patterned substrate topographies, such as photolithography (Edalat et al., 2012), electron beam lithography (Luna et al., 2011; Wang et al., 2010; Wang et al., 2012d), or self-assembled colloidal crystals (Ji et al., 2012; Wang et al., 2015a; Wang et al., 2015b; Wang et al., 2016b); however, methods of production such as lithography may be time-consuming or expensive (Wang et al., 2015b). Polyacrylamide hydrogels, which can serve as ECM-like substrates in vitro, can be produced at different stiffnesses to study the effects of matrix stiffness on cell behaviour (Macrí-Pellizzeri et al., 2015). Mechanical forces such as tension, compression, shear stress and fluid shear stress are often applied using bioreactor systems, which may rotate culture flasks, physically stretch substrates during cell growth, or pump fluid at a constant rate through the culture, while maintaining an environment conducive to cell growth (Jin et al., 2015). Electrical and magnetic stimulation is applied to cells via electrodes attached to the cell substrate (Jin et al., 2015; Tandon et al., 2009). A variety of methods exist for biophysical stimulation of stem cells.

\subsection{Surface topography}


Stem cell differentiation and phenotype can be highly sensitive to substrate topographical features (Dalby et al., 2014). Several reviews have summarised the effects of topographical cues, especially microtopography, on stem cell behaviour (Dalby et al., 2014; Griffin et al., 2015; Koegler et al., 2012; Nava et al., 2012; Nikkhah et al., 2012; Park and Im, 2015; Teo et al., 2010); thus, we only summarise the key outcomes of topographical stimulation, particularly at the submicron scale.

The effects of surface topography on stem cell phenotype are dependent on cell type, the type of topographical pattern, feature sizes, and substrate composition (Dalby et al., 2007; Lapointe et al., 2013; Murphy et al., 2014; Wang et al., 2012a; Wang et al., 2012b; Wang et al., 2012c; Wang et al., 2013a; Wang et al., 2015c). In general, substrates with nanoscale topographical features have been found to assist cell attachment (Bacakova et al., 2011). Due to the large variety of surfaces studied so far, identifying general trends in how cells react to topographical cues is a difficult endeavour (De Luca et al., 2015). For example, random nanotopographical patterning may either promote or inhibit cell-matrix adhesion depending on cell type, pattern type, and other parameters such as surface chemistry or substrate elasticity (Cha et al., 2013; Dalby et al., 2007; Dalby et al., 2014). Despite these uncertainties, a number of groups have reached important conclusions about the effects of some substrate topographies on stem cells. In a study comparing ordered and random feature distribution, highly ordered nanoscale pitted patterns were found to inhibit cell-matrix adhesion (Dalby et al., 2007). Multipotency and MSC markers in human bone marrow- and adipose-derived MSCs are retained by culture on surfaces consisting of $100 \mathrm{~nm}$-deep "pits" with $120 \mathrm{~nm}$ diameter arranged in a square lattice with a spacing of $300 \mathrm{~nm}$ between each pit (McMurray et al., 2011). Small "nanoislands", $10-20 \mathrm{~nm}$ in height, have been found to promote cell adhesion and cell spreading in several cell types, while relatively larger features of the same type (100 nm in height) inhibited cell spreading and differentiation (Dalby et al., 
2014). The geometric shape of features at the micrometre scale also plays a role in influencing MSC behaviour (Nava et al., 2012), as several studies have identified shapespecific effects on cell proliferation and differentiation (Kilian et al., 2010; Luo et al., 2008; Wan et al., 2010). There are many factors to consider when examining the effects of substrate topography on stem cells.

Culture of stem cells on nanogrooves is able to direct differentiation towards neural cell lineages, even in the absence of conventional growth factors (Kingham and Oreffo, 2013). These substrates generally require some form of surface treatment to support cell attachment, such as oxygenated plasma treatment and gelatin coatings (Kingham and Oreffo, 2013). For example, hESCs were found to differentiate into neural lineages on a gelatin-coated nanoscale groove patterned substrate (350 nm width and $500 \mathrm{~nm}$ height) (see Figure 1) (Lee et al., 2010). hESCs cultured on nanofibrils made of a collagen-carbon composite material in the absence of retinoic acid, a key component of neural induction media, differentiated towards ectodermal lineages (Sridharan et al., 2009). Nanotopographical groove $(300 \mathrm{~nm} / 300$ $\mathrm{nm}$ width/depth) or pillar (300 nm height, $300 \mathrm{~nm}$ spacing) substrate patterning promoted differentiation of human NSCs into neurons and astrocytes (Yang et al., 2013). However, these promising results are contested by the findings of several groups which report that ESCs default to neural differentiation pathways when there is insufficient signalling towards other lineages (Kingham et al., 2013). The influence of such substrates on neurogenesis requires further exploration.

Figure 1. Morphology and mesodermal, endodermal and neuronal differentiation of hESC on gelatin-coated oxygen plasma-treated nanogrooved surfaces (500 nm height, $350 \mathrm{~nm}$ width) without induction media, compared to flat control surfaces. The grooved surfaces caused cell 
elongation and alignment, and were found to promote neuronal differentiation in the absence of induction media (image adapted from Lee et al. (Lee et al., 2010) and reprinted with permission from Elsevier Ltd.). Blue $(\mathrm{DAPI})=$ nuclei. Red $($ Nestin $)=$ early differentiation marker. Green $=$ cell markers as specified. Brachyury $=$ mesoderm marker; $\operatorname{Pdx} 1=$ endoderm marker; Tuj1 = early neuronal marker.

Disordered nanoscale features, which create "nanoroughness" on the culture substrate, promote osteogenesis (Dalby et al., 2007; Dalby et al., 2014; Kingham et al., 2013; Nava et al., 2012; Wang et al., 2012b; Wittenbrink et al., 2015). When human bone marrow-derived MSCs are cultured on surfaces with $120 \mathrm{~nm}$ diameter pits with an average spacing of $300 \mathrm{~nm}$ randomly offset by $50 \mathrm{~nm}$, differentiation is promoted and targeted towards osteoblasts (Dalby et al., 2007). Completely random arrangement of the pits further promoted osteoblast differentiation, as detected by the presence of bone-specific matrix components and osteoblast adhesion molecules (Dalby et al., 2007). The results of the studies by Dalby et al. are shown in Figure 2. In hESCs, disordered nanotopographies encourage differentiation towards a mesodermal lineage resulting in osteogenesis (Dalby et al., 2014; Kingham et al., 2013). Random nanopatterning may also improve osteoblast maturation, as disordered polystyrene nanopillars and nanopores of $200 \mathrm{~nm}$ diameter induced a more stretched osteoblast morphology with increased proliferation and somewhat enhanced cell-substrate attachment (Cha et al., 2013), and osteoblasts cultured on substrates with shallow rippled patterning of $11.5 \mathrm{~nm}$ feature height increased proliferation and developed pseudopodia which aligned along the ripples, although the cells themselves were not aligned (Wittenbrink et al., 2015). These studies demonstrate that a disordered substrate nanotopography can assist osteogenesis. 
Figure 2. Maintenance of human MSC multipotency on ordered $120 \mathrm{~nm}$ diameter, $100 \mathrm{~nm}$ depth pit square lattice patterns in standard media. Multipotency is maintained on highly ordered patterns (SQ) compared to patterns with a random $50 \mathrm{~nm}$ offset (NSQ50) (image adapted from McMurray et al. (McMurray et al., 2011) and reprinted with permission from Nature Publishing Group). Green = ALCAM or STRO-1 (MSC markers), red $=$ actin (indicating cell morphology), blue $=$ nuclei.

Substrates patterned with microscale grooves promote differentiation and maturation of stem cells into cardiomyocytes. Fibronectin-coated microgrooves with dimensions of $4 \mu \mathrm{m} / 10 \mu \mathrm{m}$ (width/depth) and $10 \mu \mathrm{m}$ spacing improved the phenotype of hiPSC-derived cardiomyocytes without significant changes in gene expression (Rao et al., 2013). The cardiomyocytes aligned longitudinally along the grooves, had elongated morphology and showed improved sarcoplasmic reticulum organisation, visible as aligned cell striations (Rao et al., 2013), making them more similar to mature native heart cells (Hartman et al., 2015). Additionally, there were improvements in calcium cycling (Rao et al., 2013), the changes in intracellular $\mathrm{Ca}^{2+}$ concentration necessary for cardiomyocyte beating and other $\mathrm{Ca}^{2+}$-dependent cellular processes (Marks, 2013). These iPSC-derived cardiomyocytes, cultured on microgrooved substrates, were faster to reach maximum concentrations of $\mathrm{Ca}^{2+}$ transients during spontaneous beating and had a more synchronised release of $\mathrm{Ca}^{2+}$ from the sarcoplasmic reticulum (Rao et al., 2013). These results indicate that microgrooved substrate patterning improves the maturation and function of cardiomyocytes differentiated from iPSCs. While nanogrooved substrates have been used for maturation of cardiomyocytes (Wang et al., 2011), it has not been widely used for the PSC differentiation. 
For some time, systematic analysis of the effects of nanotopographical patterning on stem cells and rational surface pattern design has been a major challenge (Unadkat et al., 2011), due to a lack of understanding of many underlying mechanisms and the huge range of topographical features and pattern types possible (Hulsman et al., 2015). To address this issue, "screening" approaches such as the TopoChip have been developed to investigate the cellular response to over 2000 different surfaces at a time (Unadkat et al., 2011). These approaches have contributed to the discovery of several interesting trends in how nanotopography can influence stem cell behaviour. For example, one study examining feature size, density and "roundness" found that smaller topographical features arranged at higher density promoted hiPSC proliferation and pluripotency (Reimer et al., 2016). Correlations between cell morphological features and more complex cell behaviours, such as human MSC differentiation, have also been found using these techniques (Unadkat et al., 2013). The invention of high-throughput methods to examine how substrate topography modulates stem cell behaviour has been a major development in this area.

Investigation into the effects of surface topography on cell behaviour needs to take surface protein adsorption into account (De Luca et al., 2015). The process of cell adhesion to substrates first requires the adsorption of proteins from the surrounding fluid (culture media in vitro or interstitial fluid in vivo), to which cells then attach (Koegler et al., 2012; Nune and Misra, 2014). The initial surface properties of these substrates is an important factor in determining the amount and characteristics of the proteins that are adsorbed, and therefore the interactions between the substrate and cells (Koegler et al., 2012). Surface patterning is known to affect protein adsorption from culture media (Koegler et al., 2012; De Luca et al., 2015; Pegueroles et al., 2010), and the process of contact guidance, by which cells detect and respond to contact-dependent environmental signalling molecules, has been well-studied (Rørth, 2011). Despite this, it is still uncertain whether surface topography directly affects 
cell attachment mechanisms, or whether it in fact influences protein adsorption from solution to indirectly control cell behaviour. The interaction between surface protein adsorption and substrate topography requires further study (Koegler et al., 2012).

\subsection{Substrate stiffness}

One major development in the area of biophysical cell manipulation has been the discovery that substrate stiffness is able to direct cell behaviour (Wang et al., 2011; Zhang and Kohn, 2012) and human stem cell lineage specification (Bacakova et al., 2011; Engler et al., 2006; Tse and Engler, 2011; Wang et al., 2012e). A matrix reflecting the stiffness of a particular native tissue will direct human MSC differentiation towards that tissue type (Engler et al., 2006). Soft brain-mimicking surfaces $(0.1-1 \mathrm{kPa})$ were neurogenic, harder muscle-like surfaces $(8-17 \mathrm{kPa})$ were myogenic, and very stiff bone-like surfaces $(25-40 \mathrm{kPa})$ were osteogenic, as shown in Figure 3 (Vidane et al., 2013). Adipogenesis of human adiposederived MSCs on soft substrates similar to native adipose tissue $(2 \mathrm{kPa})$ can occur even in the absence of inductive soluble chemical factors (Young et al., 2013). Non-muscle myosin II activity was found to be the mechanism behind matrix stiffness-determined human MSC differentiation (Bacakova et al., 2011; Engler et al., 2006). Regulation of MSC behaviour is influenced not only by the degree of matrix stiffness, but also by gradients or variation in stiffness. Human MSCs cultured on hydrogel with an elasticity gradient of around $1 \mathrm{kPa} / \mathrm{mm}$ showed significant migration towards stiffer areas, and tended to differentiate towards myogenic lineages (Tse and Engler, 2011). The mechanism behind modulation of MSC behaviour by substrate stiffness has been investigated. There are a number of known mechanosensitive cell molecules expressed in MSCs, including type A lamin, found at the nuclear membrane, which is important in maintaining nuclear integrity and is able to influence gene transcription (Kulangara et al., 2014). Expression of type A lamin has been 
found to increase in cells cultured on substrates with increased stiffness, and therefore may play a role in mediating the effects of substrate elasticity on MSC differentiation (Swift et al., 2013). Overall, it is clear that substrate stiffness can have a profound effect on MSC behaviour.

Figure 3. MSC differentiation is influenced by matrix stiffness: in "identical media conditions", soft (0.1-1 kPa) matrices are neurogenic, matrices of intermediate stiffnesses (8$17 \mathrm{kPa})$ are myogenic, and rigid (25-40 $\mathrm{kPa})$ matrices are osteogenic. The expression of $\beta 3$ tubulin (cytoskeletal neural marker), MyoD (muscle transcription factor) and CBF $\alpha 1$ (osteoblast transcription factor) in green mark cell differentiation into neural, muscle, or osteoblast-like cells respectively, as indicated by the arrows (image adapted from Engler et al. (Engler et al., 2006) and reprinted with permission from Cell Press). Blue $=$ nuclei; green $=\beta 3$ tubulin, $\mathrm{MyoD}$, or $\mathrm{CBF} \alpha 1$, as indicated in each row.

The generation and behaviour of hiPSCs is also influenced by matrix stiffness. Very soft $(<$ $0.1 \mathrm{kPa}$ ) matrices appear to enhance reprogramming of human fibroblasts into hiPSCs by increasing expression of pluripotent markers (Higuchi et al., 2014b). This finding could contribute to development of more efficient methods of forming iPSCs (Higuchi et al., 2014b), and agrees with earlier observations of the correspondence between cell type and native-like matrix stiffness, as the native environments of stem cells in vivo tend to have a lower tissue modulus than the surrounding tissue (Akhmanova et al., 2015). The neurogenic potential of low stiffness matrices was further characterised in a study finding that hPSC culture on soft matrices $(0.1-0.7 \mathrm{kPa})$ for five days promoted formation of early neural 
ectoderm and increased differentiation into neurons and dopaminergic cells, with no effect on proliferation (Keung et al., 2012). As with MSCs, iPSC differentiation appears to be guided in part by matrix stiffness.

The influence of matrix stiffness on cardiac cell differentiation and development has been the subject of significant research (Engler et al., 2008; Forte et al., 2012; Hazeltine et al., 2014; Tallawi et al., 2015), partly due to its potential in clinical and scientific applications. Again, the native environment should be taken into consideration. Elasticity of the ECM is a crucial factor in heart development in both foetal and postnatal stages. The development of the thicker left ventricle wall occurs in response to physiological increase of mechanical load during foetal development (Zimmermann, 2013). Matrix elasticity varies during human development, from around $10 \mathrm{kPa}$ in embryonic myocardium (Engler et al., 2008) to $20-500$ $\mathrm{kPa}$ in adult myocardium (Tallawi et al., 2015). In vitro, cardiomyocytes grown on substrates with a similar stiffness to native myocardium were most well-developed, as they had a larger calcium cycling amplitude, better-defined sarcomeres, and increased twitch power, all resulting in a more mature phenotype (Tallawi et al., 2015). Matrix stiffness and other external forces were found to affect these physiological features of cardiomyocyte function by influencing the organisation and assembly of contractile protein fibres (Tallawi et al., 2015). Biomimetic substrate stiffness could help produce functional, mature cardiomyocytes from stem cells.

\subsection{Compression and stretching}

Mechanical forces are an important factor in embryonic tissue development in vivo and PSC phenotype in vitro (Nsiah et al., 2014). Some types of forces maintain pluripotency of stem cells by enhancing proliferation and inhibiting differentiation, while other forces stimulate differentiation into certain lineages (Geuss and Suggs, 2013). Cyclic strain appears to help 
maintain stem cell phenotype, as application of $10 \%$ strain at 10 - 30 cycles/min has been found to inhibit hESC differentiation (Saha et al., 2006). It has been hypothesised that a constantly applied shear stress of under 8 dynes $/ \mathrm{cm}^{2}$ could help maintain pluripotency in hiPSCs (Geuss and Suggs, 2013). Additionally, "dynamic culture" in the form of orbital shaking at 100 rounds per minute significantly improved the efficiency of mouse fibroblast reprogramming into iPSCs (Sia et al., 2016). However, the exact effects of such mechanical forces, and how they might relate to events during native embryonic development, are generally still unclear (Ahsan and Nerem, 2010).

Mechanical forces also influence the phenotype and morphology of PSC-derived cells. For example, hiPSC- and hESC-derived vascular smooth muscle cells, were found to align perpendicular to the axis of strain and increase ECM gene expression when cultured under uniaxial tensile strain of 7\% elongation for 24 hours, as shown in Figure 4 (Wanjare et al., 2015). When cultured under $1 \mathrm{~Hz}$ cyclic 5\% uniaxial strain, hiPSC-derived neural crest stem cells aligned perpendicular to the axis of strain and expressed higher levels of the smooth muscle cell lineage marker calponin-1 (Li et al., 2012). Circumferential strain of 7\% elongation, mimicking bloodflow, promoted expression of collagen III and elastin (largely responsible for blood vessel strength) in mature hPSC-derived vascular smooth muscle cells (Wanjare et al., 2015). In the native cardiovascular system, fluid shear stress influences endothelial cell lineage specification, morphological alignment, and phenotype to different degrees depending on the magnitude and duration of the stress (Levesque and Nerem, 1985). Mechanical forces could be used to further modulate the phenotype of cells generated from PSC differentiation to improve their maturity and function. 
Figure 4. Uniaxial strain of $7 \%$ elongation applied for 24 hours to human pluripotent stem cell-derived vascular smooth muscle cells, cultured in normal smooth muscle cell growth media, cause cell alignment perpendicular to the direction of strain (image adapted from Wanjare et al. (Wanjare et al., 2015) and reprinted with permission from the American Physiological Society). Direction of strain is indicated by arrows. Con-vSMCs $=$ contractile vascular smooth muscle cells; hPSC $=$ human pluripotent stem cell; $\mathrm{mSMLCs}=$ mature smooth muscle-like cells; vSMCs = vascular smooth muscle cells. Blue = nuclei; green = actin; red = calponin, early vascular smooth muscle marker.

Compressive and tensile forces have various effects on MSCs, distinct from those found in ESCs. Mechanical forces, such as those driven by fluid flow, cell-cell contact and cell-matrix interaction, are part of the complex regulatory signals controlling MSC behaviour in vivo (Hao et al., 2015; Liu and Lee, 2013). Human bone marrow-derived MSCs with high intracellular tension differentiate towards osteoblasts, while low intracellular tension or low actin/myosin interaction skews differentiation towards adipocytes (McMurray et al., 2011). Additionally, cyclic strain appears to promote myogenesis in human bone marrow-derived MSCs (Gong and Niklason, 2008). $0.5 \pm 4 \mathrm{dyn} / \mathrm{cm}^{2}$ oscillating shear stress was found to promote the differentiation of human bone marrow-derived MSCs towards adipogenic and osteogenic lineages, depending on the time duration of force, via changes in actin arrangement which modulate Wnt/ $\beta$-catenin signalling (Kuo et al., 2015). Cyclic uniaxial tension was found to upregulate osteogenic gene expression in human bone marrow-derived MSCs while dynamic compression upregulated chondrogenesis-associated genes; these changes were again mediated by Wnt/ $\beta$-catenin signalling (Haudenschild et al., 2009). Shear stress, which plays a major role in endothelial cell behaviour in the form of bloodflow in vivo, 
also appears to stimulate human MSCs from various tissue origins to differentiate into endothelial-like cells (Dan et al., 2015). The effects of mechanical strain differ from one cell type to another.

\subsection{Electric or magnetic fields}

Electrical stimulation and conduction is of particular interest in cardiac cell lineage differentiation because of its importance in embryonic cardiac development (Cameron et al., 1993; Chan et al., 2013) and maintenance of native heart function (Cutler et al., 2011). Cardiomyocytes cultured under electrical field stimulation have a greater resemblance to native cardiac tissue in terms of cell elongation, organisation, alignment/orientation, and some aspects of metabolic activity (Tandon et al., 2009). The timing of electrical stimulation during cardiomyocyte development is important, as applying an electrical field too early in development causes protein accumulation and inhibits development of contractile behaviour, while applying it when cells are already mature means there is no effect on cell assembly (Tandon et al., 2009). Electrical stimulation applied during development of hiPSC-derived cardiomyocytes to pace beating has been found to significantly improve the resulting cell phenotype, as in vitro culture under a pulsed biphasic electrical field of $2 \mathrm{~V} / \mathrm{cm}$ every $4 \mathrm{~ms}$ ( 2 ms per polarity) caused hiPSC-derived cardiomyocytes to become more similar in structure to native cardiomyocytes (Hirt et al., 2014). The resulting cells were more anisotropically aligned, longer and slimmer in morphology, and had a higher cytoplasm-tonucleus ratio, greater contractile mass and generation of force, and more organised crossstriation compared to cells grown without electrical stimulation (Hirt et al., 2014). Electrical stimulation during stem cell culture therefore has an important influence on cardiomyogenesis. 
Electrical stimulation is also of interest in neurogenesis, due to the role of electrical conduction in embryonic development, normal neuron function, and regeneration after neuron damage (Park et al., 2012). External electrical fields can be used to guide neural precursor migration, neuron migration, and neurite outgrowth, which are essential steps in neurogenesis (Yao et al., 2011). Neurogenic behaviour is highly sensitive to electrical stimulation; neural stem cells derived from hESCs were found to migrate towards the positive charge in a small direct current electrical field of only $16 \mathrm{mV} / \mathrm{mm}$ (Feng et al., 2012). Human neural stem cells became elongated in morphology and showed increased neural differentiation when cultured under an electrical field of $1 \mathrm{~V} / \mathrm{cm}$ applied to an electrically conductive polymer substrate (Pires et al., 2015). Electrical fields of $100 \mathrm{mV} / \mathrm{min}$ applied for $10 \mathrm{~min} /$ day have been found to induce neuron-like filopodia morphology and increased neural gene expression in human bone marrow-derived MSCs, without the addition of induction media (Thrivikraman et al., 2014). Neurogenesis is greatly influenced by electrical cues.

The effects of electromagnetic stimulation on stem cells has been examined by several groups (Abbasnia et al., 2015; Cho et al., 2012; Kang et al., 2013b; Ma et al., 2014), with some controversial results (Fayol et al., 2013) likely due to differences in experimental conditions (Kang et al., 2013b). For example, there have been conflicting studies into the effect of superparamagnetic iron oxide (SPIO) labelling of human MSCs for magnetic resonance imaging (MRI), as some indicate a negative effect on chondrogenesis (Kostura et al., 2004) while others report no significant changes in cell phenotype (Arbab et al., 2005). Osteogenic differentiation in human adipose-derived MSCs has been found to either increase or decrease depending on electromagnetic field frequency and magnetic flux density: osteogenic marker expression was promoted at $30-45 \mathrm{~Hz}, 1 \mathrm{mT}$ but inhibited at $7.5 \mathrm{~Hz}, 1 \mathrm{mT}$ (Kang et al., 2013b). In one study, human bone marrow-derived MSCs showed decreased proliferation and 
increased expression of neural cell markers when cultured with maintenance culture media in extremely low-frequency electromagnetic fields (sinusoidal, $1 \mathrm{mT}, 50 \mathrm{~Hz}$ ) (Cho et al., 2012). These results have implications for procedures like MRI used in tissue engineering, which involves magnetic labelling of stem cells (Fayol et al., 2013). Additionally, research into how magnetic fields affect stem cells could reveal the mechanisms behind treatments like repetitive transcranial magnetic stimulation for neurological disease, or low-frequency electromagnetic fields for bone fractures (Abbasnia et al., 2015; Kang et al., 2013b). Overall, the effects of electromagnetic stimulation are still unclear.

\subsection{Ultrasound stimulation, photostimulation, and combined biophysical cues}

In addition to cell adhesion-dependent forces such as surface topography, substrate stiffness, and mechanical forces, the effects of other non-contact-dependent forms of biophysical stimulation on stem cells have been studied. These include low-intensity ultrasound, and light of varying wavelengths. Additionally, some studies have investigated how different forms of biophysical stimulation influence stem cells when applied in combination.

Ultrasound frequencies can modulate stem cell behaviour, with important implications for present and future practical applications. Low-intensity ultrasound enhances stem cell differentiation into osteoblasts and is used in the clinical treatment of bone fractures and bone defects (Claes and Willie, 2007; Kang et al., 2013a). These osteogenic effects of ultrasound persist in microgravity environments, suggesting that ultrasound could be used as treatment for osteoporosis caused by disuse (Uddin and Qin, 2013). A study examining the influence of ultrasound frequency on effectiveness found that, when applied continuously, 1.5 MHz was most effective for promoting osteogenesis in human adipose-derived MSCs (Kang et al., 2013a). The mechanisms behind the effects of ultrasound stimulation on human MSCs have been found to involve soluble receptor activator of nuclear factor kappa B ligand (sRANKL) 
(Chiu et al., 2015). Low-intensity ultrasound applied at $500 \mathrm{~mW} \mathrm{~cm}^{-2}$ was found to increase proliferation and differentiation in hiPSC-derived neural crest stem cells, raising the possibility of using ultrasound in nerve cell regeneration or tissue engineering ( $\mathrm{Lv}$ et al., 2013). Ultrasound stimulation has been a particular success in the area of clinical biophysical stem cell manipulation.

Light stimulation alone can also influence stem cell behaviour. Helium-neon lasers emitting light at $632.8 \mathrm{~nm}$, used clinically to promote wound healing, were found to promote human epidermal stem cell proliferation and migration, which are processes involved in skin selfrenewal and regeneration (Liao et al., 2014). In one study, blue light inhibited human bone marrow-derived MSC proliferation at wavelengths of $455 \mathrm{~nm}$ and $470 \mathrm{~nm}$ (Wilner, 2010). In other species such as mice, MSC osteogenesis and bone formation was improved by application of blue light at $405 \mathrm{~nm}$, which improved extracellular calcification (Kushibiki and Awazu, 2009). Photostimulation at different wavelengths can have various effects on stem cells.

Some studies have also examined the effects of combining different types of biophysical stimulation. Human neural stem cells cultured on semiconductive reduced graphene oxide nano-meshes under near-infrared lasers at $808 \mathrm{~nm}$ had a skewed differentiation towards neurons rather than glial cells (Akhavan et al., 2015). Experiments that combined electrical stimulation and topographical cues showed that they both appear to affect the same cell elongation pathways that assist cell alignment and organisation, although topography had a more significant effect than electrical stimulation (Tandon et al., 2009). Different forms of biophysical stimulation may be used together, with interesting insights. 


\section{Biochemical stimulation}

Current protocols for directed stem cell differentiation primarily involve the addition of growth factors and chemical reagents (Efthymiou et al., 2014; Trounson, 2006). More recently, new reagents such as small molecules which target specific intracellular pathways have been proposed for stem cell differentiation protocols, and are now widely used in a soluble form in culture media (Xu et al., 2013). At the same time, studies have focused on immobilisation or pre-coating bioactive signals on cell culture substrates or the surface of implantable scaffolds (Bacakova et al., 2011; Chen et al., 2011; Chuah et al., 2015; Duffy et al., 2014; Kang et al., 2014; Kuddannaya et al., 2013; Lu et al., 2006; Nagaoka et al., 2010; Yamada et al., 2014). This has the potential to establish more defined culture systems and be used in future clinical applications, such as commercialised cell culture tools (Higuchi et al., 2014a; Wang et al., 2016a) and tissue engineered implants (Salerno et al., 2013). This section discusses the effect of soluble factors in medium and surface-immobilised biosignals on stem cell culture, and lists the remarkable outcomes in Table 2.

\subsection{Soluble factors in media}

The development of methods using soluble biochemical signals to fully differentiate stem cells into different cell types is the subject of extensive research and has been successful to varying degrees (Budiatzky and Gepstein, 2014; Efthymiou et al., 2014; Mallanna and Duncan, 2013). In general, an optimised recipe and a longer the culture time improve the maturation of differentiated stem cells. However, there are often limitations in producing fully mature and functional adult cells (e.g. cardiomyocytes, hepatocytes and pancreatic cells) from current protocols, which use various cocktails of growth factors at different concentrations (Efthymiou et al., 2014). The efficiency of protocols and purity of differentiated cell populations may also be limited. Here, we will explore some current 
techniques for MSC and PSC differentiation into several key lineages, with a focus on particular achievements and difficulties in these methods.

MSC differentiation is traditionally induced with the addition of soluble growth factors and other chemicals to culture media. For instance, in osteogenesis, these are generally ascorbate, $\beta$-glycerophosphate, and bone morphogenetic proteins (BMPs) or dexamethasone (DEX)) (Cook and Genever, 2013). BMPs such as BMP-2 stimulate the expression of major osteogenic genes such as osteopontin, osteocalcin and Runx2 (Runt-related transcription factor 2) (Sun et al., 2015). Adipogenesis requires DEX, isobutylmethylxanthine, indomethacin and insulin (Cook and Genever, 2013). DEX, a synthetic glucocorticoid, is thought to influence Hedgehog signalling in MSCs (Ma et al., 2013). Transforming growth factor beta (TGF $\beta$ ) is added to human adipose-derived or bone marrow-derived MSCs cultured at a high density or as "micromass pellets" for chondrogenesis (Cook and Genever, 2013; Pelttari et al., 2008). In addition to these mesodermal lineages, MSCs may be transdifferentiated into ectodermal and endodermal lineages by certain soluble growth factors (Brzoska et al., 2005; Gao et al., 2014; Li et al., 2013). While these differentiation methods are widely used, biochemical induction of MSC differentiation still has its limitations, particularly in the maturity, functionality, cell phenotype, and tissue structure of the resulting cells (Somoza et al., 2014). MSCs also play an important role in paracrine signalling to other stem cells. For example, MSC co-culture or MSC-conditioned media have been found to regulate neural stem cell differentiation via the secretion of soluble signals (Bai et al., 2007; Yang et al., 2015). Overall, the types of chemicals that are applied in MSC differentiation depend on the cell lineage being targeted.

Biochemical differentiation of PSCs in vitro is traditionally achieved by uncontrolled spontaneous differentiation, or by directed differentiation towards specific cell lineages. 
Spontaneous differentiation can be induced by culture of PSCs as embryoid bodies (EBs), with various medium compositions to "bias" differentiation towards certain lineages (Hazeltine et al., 2013). Spontaneous differentiation produces a mixed population of many cell lineages from all germ layers (Sridharan et al., 2009), and the efficiency of differentiation and percentage of specific cells is uncontrollable and generally low. These differentiation methods are inefficient, with a yield of $1-25 \%$ depending on the cell type in question (Budniatzky and Gepstein, 2014). Spontaneous differentiation of PSCs produces a large range of ectodermal, mesodermal and endodermal cell types but cannot yet be used for largescale applications. Directed differentiation with soluble factors has been successful to various degrees in generating many cell types, such as cardiomyocytes (Hartman et al., 2015), neural cells (Ross and Akimov, 2014), pancreatic $\beta$ cells (Agulnick et al., 2015), and hepatocytes (Schwartz et al., 2014). However, these protocols generally involve multiple steps with many different expensive biochemical factors to mimic in vivo development (Tabar and Studer, 2014), which can result in loss of cells, inefficient differentiation, or low cell type purity (Budniatzky and Gepstein, 2014). In particular, production of mixed cell populations can pose a problem, since efficient methods of cell sorting are required before these stem cell technologies can be used in tissue engineering and other applications. Clinical applications of stem cell differentiation would require either a differentiation efficiency of close to $100 \%$ or a large-scale method to purify selected cell types from a mixed population (Budniatzky and Gepstein, 2014). Spontaneous differentiation and directed differentiation of PSCs using soluble biochemical factors has been successful in many respects, but some disadvantages still exist.

Cardiomyocyte differentiation from PSCs is one area of great interest that has seen significant advances in soluble chemical differentiation methods (Hartman et al., 2015; Mummery et al., 2012). Spontaneous differentiation and growth factor-based protocols have 
been established for generating myocytes (Laflamme et al., 2007; Yan et al., 2009; Yang et al., 2008). Functional cardiomyocytes can be produced by culture of EBs in differentiation media containing non-essential amino acids, L-glutamine, $\beta$-mercaptoethanol and $20 \%$ foetal bovine serum (FBS), followed by micro-dissection of beating areas (Zhang et al., 2009). Coculture systems have also been established for the generation of cardiomyocytes from human iPSCs (hiPSC) and human ESCs (hESC) (Yoshida and Yamanaka, 2010), in which these human PSCs (hPSC) are cultured with other cell types such as mouse visceral-endoderm-like cells (Mummery et al., 2012). However, these methods are generally difficult to scale up and do not achieve the efficiency or cell purity required for potential clinical applications unless cell sorting methods are applied (Budniatzky and Gepstein, 2014). More recently, differentiation protocols using small molecules have been developed, and are able to generate cardiomyocytes in well-defined, scalable conditions with greater speed and differentiation efficiency (Fonoudi et al., 2015). These protocols primarily modulate Wnt signalling, which has an important role in native cardiac development (Lian et al., 2012). The main ingredients of these protocols are small molecule Wnt pathway inhibitors or activators, BMP inhibitors, shRNA, and/or other molecules, each added at specific time points (Aguilar et al., 2015; Fonoudi et al., 2015; Zhang et al., 2013). With the development of more efficient and welldefined cardiomyocyte differentiation protocols, routine use of stem cell-derived cardiomyocytes in research and the clinic could soon be possible.

Neurogenesis from hPSCs is another major area of study, owing to its potential clinical applications for treating neural disease or providing models for research into human brain development and disease (Ross and Akimov, 2014; Stoll et al., 2014). Many neurogenic protocols have been developed to date, with various advantages and limitations (Ambasudhan et al., 2014; Srikanth and Young-Pearse, 2014; Suter and Krause, 2008). Common protocols for human neurogenic differentiation involve the differentiation of ESCs grown as EBs into 
neural stem cells (NSCs), which form a mixture of neurons, oligo-dendrocytes and astrocytes in in vitro culture under the influence of retinoic acid (Wesselschmidt and McDonald, 2006). Populations of astrocyte-like cells with relatively high purity $(>90 \%)$ have been produced using retinoic acid, the growth factors sonic hedgehog (SHH), epidermal growth factor (EGF), basic fibroblast growth factor (bFGF) and ciliary neurotrophic factor (CNTF), and 10\% FBS (Krencik et al., 2011). A serum-free culture system, dubbed the "neurosphere assay", uses EGF to maintain NSCs as undifferentiated, proliferating neurospheres which later differentiate into neuroglial cells when removed from EGF media and allowed to attach to a substrate (Chojnacki and Weiss, 2008). These methods for in vitro neural cell generation are based on mimicry of embryonic in vivo neural development via major signalling pathways including the Notch, Wnt- $\beta$-catenin, FGF2 and BMP pathways (Suter and Krause, 2008). Current methods based on small molecules rather than growth factors generate neural cells from PSCs by dual SMAD inhibition and Wnt activation (Chambers et al., 2009; Chambers et al., 2016). These small molecules can be used in combination with growth factors to induce differentiation into specific cell types in greater proportions, such as posterior neural crest cells, melanocytes (Mica et al., 2013), and sensory neurons (Chambers et al., 2012). There has been significant success in the area of hPSC neurogenesis, with numerous clinical trials using human iPSC and ESC technology to treat spinal cord injuries and retinal diseases (Kimbrel and Lanza, 2015). However, generating mature neural cells from PSCs remains a challenge. Though further research is still needed, neurogenic stem cell therapy is well on the way to realising its potential in many applications.

The derivation of several pancreatic cell types from stem cells has had highly promising results. Clinical trials by the company ViaCyte Inc. are now testing a Type I diabetes treatment based on an implant containing hESC-derived pancreatic endoderm (Agulnick et al., 2015; Kimbrel and Lanza, 2015). These functional insulin-producing pancreatic $\beta$-cells 
were generated from hESCs by mimicking in vivo pancreatic development through the addition and removal of the growth factors activin, Wnt, fibroblast growth factor 10 (FGF10), KAAD-cyclopamine (CYC), all-trans retinoic acid, the $\gamma$-secretase inhibitor DAPT, exendin4 (Ex4), insulin-like growth factor 1 (IGF1) and hepatocyte growth factor (HGF) over five stages of growth (D’Amour et al., 2006). Other more recently developed methods involve addition of Activin A, fibroblast growth factors (FGFs) and retinoic acid, the small-molecule BMP inhibitor LDN, and certain gene inhibitors such as Smoothened antagonists (SANT) (Pagliuca et al., 2014; Rezania et al., 2014). However, despite the success of these methods, there are still some problems to overcome: the complexity of the multistep protocols used, the cost of production, and ensuring that the cell generation processes remain reliable after scaling up (Schulz, 2015). Differentiation of PSCs into pancreatic cells has proven to be a successful and promising area in tissue engineering, but there are still limitations to be overcome.

Several methods have been established for the differentiation of PSCs to hepatocyte-like cells and pancreatic-like cells (Mallanna and Duncan, 2013; Rostovskaya et al., 2015; Schwartz et al., 2014). Hepatocytes perform hundreds of functions, including metabolic, synthetic, immunologic, and detoxification processes (Bhatia et al., 2014). Generation of hepatocytelike cells from hPSCs primarily involve sequential addition and removal of activin-A, BMP4, bFGF, HGF, oncostatin M (OSM) and, in some protocols, DEX at specific time points (Mallanna and Duncan, 2013; Schwartz et al., 2014). However, these cells are more similar to foetal than adult hepatocytes (Baxter et al., 2015), and current protocols are still unable to generate fully functional, mature hepatocytes (Huang et al., 2011). Overall, while there have been some successes in this area, several challenges still exist and the derivation of hepatic cells from PSCs is an area that requires more research. 


\subsection{Surface-immobilised biosignals}

Surface coatings, such as ECM proteins or protein-enriched mixtures like Matrigel ${ }^{\circledR}$, are routinely used in stem cell culture to mimic the in vivo extracellular matrix (ECM). The importance of the ECM in controlling cell behaviour via presentation of both soluble and insoluble factors is well-known (Gattazzo et al., 2014; Walters and Gentleman, 2015), and taking advantage of this as a cell culture tool has been a significant area of research (Minardi et al., 2016). Matrigel, a gelatinous mixture secreted by Engelbreth-Holm-Swarm (EHS) mouse sarcoma cells, consists of a large number of key proteins and growth factors which are known to influence many cellular processes, including stem cell self-renewal (Villa-Diaz et al., 2013). Gelatin is another relatively cheap option and is often used to improve cell attachment to culture substrates (Bacakova et al., 2011). While Matrigel is still most commonly used in cell culture, it has some insurmountable disadvantages such as containing undefined components and being itself an exogenous murine product, which is an obstacle to clinical applications (Villa-Diaz et al., 2013). Thus, non-xenogeneic and well-characterised alternatives are being continuously explored (Burridge et al., 2014; Hazeltine et al., 2013; Rowland et al., 2010). There are a number of surface protein coatings available for use in cell culture.

The reasons for using substrate coatings may differ depending on cell type. Surface protein coatings are frequently used in hPSC culture because they are anchorage-dependent cells and require some form of matrix to serve as an ECM (Villa-Diaz et al., 2013). In contrast, feederfree human MSC culture does not require protein coatings on substrates. Instead, 10\% FBS is usually added to culture media to support cell attachment and growth (Jung et al., 2012). FBS contains many cell adhesive or non-adhesive biomolecules, including, fibronectin, vitronectin and albumin as well as growth factors, hormones, amino acids, sugars and lipids which are 
important in stem cell culture. The adsorption of proteins and biomolecules from FBS onto the substrate surface, rather than prior surface modification, is hypothesised to promote cell adhesion (Dånmark et al., 2012). However, very little is known about the time-dependent composition of the protein layer and the role it plays. While surface modifications (e.g. protein or polymer coatings) are not strictly necessary for MSC culture, they can still affect MSC behaviour (Kang et al., 2014). For example, when used alongside neuronal induction media containing $20 \%$ FBS, Matrigel was found to promote neuronal differentiation of human bone marrow-derived MSCs and, at higher coating densities of $50 \mu \mathrm{g} / \mathrm{cm}^{2}$ (compared to $5 \mu \mathrm{g} / \mathrm{cm}^{2}$ ), increase proliferation efficiency (Qian and Saltzman, 2004). Polyacrylate-based hydrogel substrates have also been developed to maintain the multipotency and self-renewal of human adipose-derived MSCs in long-term culture, as well as allow thermally modulated, enzyme-independent cell harvesting (Duffy et al., 2014). Polyacrylamide and polyacrylate hydrogels can not only serve as ECM-like substrates in vitro but can also be produced with specific elasticities and biochemical compositions (Macrí-Pellizzeri et al., 2015). Different substrate coatings may be applied for various effects on human PSC and MSC culture.

Direct surface modification is another method that has been used to influence cell behaviour. Protein coatings, such as Type I collagen (Chuah et al., 2015; Kuddannaya et al., 2013) or fibronectin (Kuddannaya et al., 2013; Wang et al., 2012e; Yamada et al., 2014), can be applied to facilitate attachment of MSCs and iPSCs to hydrophobic surfaces like polydimethylsiloxane (PDMS). Different surface properties provided by these modifications can affect the density and configuration of protein adsorption prior to cell culture or from media, which in turn affects cell adhesion and growth (De Luca et al., 2015). In addition to supporting cell attachment, immobilised ligands may be used to influence cell signalling. Immobilised biomolecules such as signalling proteins can stimulate cell pathways by mimicking in vivo juxtacrine signalling which usually occurs at cell-cell or cell-matrix 
interfaces (Alberti et al., 2008). Several studies have examined the effect of immobilised ligands on cell signalling in human stem cells (Re'em et al., 2010; Russo et al., 2015; Santiago et al., 2006). Grafting bioactive peptides on topographical patterned surfaces can further alter the mechanism (Wang et al., 2012d) and speed of cell adhesion as well as the overall performance (Wang et al., 2013b; Wang et al., 2013c). Air plasma treatment of substrates improves cell attachment by adding functional groups that enhance surface hydrophilicity (Epifanio et al., 2015). However, this treatment alone cannot support stem cell growth as it lacks biochemical functions, so culture media or a protein coating is still required. Surface modification techniques can therefore be used to influence cell-substrate interactions.

\section{Combining chemical and physical stimulation}

Often, novel methods of stem cell culture involving biophysical stimulation are studied in combination with established biochemistry-based protocols. The effects of mechanical cues on stem cell differentiation in conjunction with soluble chemical factors, particularly those found in induction media, has been examined by many groups (Table 3). More importantly, increasing evidence is showing that a combination of chemical and physical stimulation could be a solution to generate functionally matured cells in vitro through synergistic effects (Engler et al., 2006; Kabiri et al., 2012; Li et al., 2015), and physical stimulation could potentially even replace some forms of chemical stimulation (Ahsan and Nerem, 2010).

Experiments that combine conflicting biophysical and biochemical cues may help ascertain the level of interaction or competition between these factors. For example, in the presence of both adipogenic and osteogenic induction media, stiffer matrices promote osteogenesis despite the presence of adipogenic media (mixed with osteogenic media), whereas softer 
matrices promote adipogenesis despite the presence of osteogenic media (mixed with adipogenic media) (Guvendiren and Burdick, 2012). Human MSCs cultured on stiffer matrices $(4.47 \mathrm{kPa})$ with adipogenic induction media had lower adipogenic ability compared to those cultured on softer matrices $(1.37 \mathrm{kPa})$ (Hwang et al., 2015). In another study, human bone marrow-derived MSCs cultured on nano-patterned topography shown to maintain multipotency were able to partially maintain stem cell phenotype even in differentiation media, as these MSCs had lower differentiation levels compared to MSCs cultured solely in differentiation media (McMurray et al., 2011). These and similar studies may reveal in greater detail how cells respond to physical and chemical cues.

Several groups have examined the combined effects of biochemical and biophysical stimulation. For example, hESC-to-cardiomyocyte differentiation is promoted by cell culture on native heart-like substrate stiffness in the presence of the Wnt secretion inhibitor IWP-4 and a glycogen synthase kinase-3 (Gsk3) inhibitor (Hazeltine et al., 2014). Electrical stimulation has been shown to improve the maturation of cardiomyocyte-like cells derived from hESCs differentiated in cardiomyocyte induction media, as shown in Figure 5 (Chan et al., 2013). Cell aggregation and three-dimensional culture combined with the soluble growth factors IWR1 (a Wnt pathway inhibitor), BMP-4, lithium chloride, and microRNA-206 inhibitor was able to induce cardiomyocyte differentiation from skeletal muscle-derived stem cells (Tchao et al., 2014). Ultrasound stimulation has also been studied in conjunction with biochemical stimulation. Low-intensity ultrasound pulses applied to human bone marrowderived MSCs cultured on RGD-grafted oxidised sodium alginate/N-succinyl chitosan hydrogel promoted osteogenesis and differentiation towards endothelium (Wang et al., 2014). $5 \mathrm{MHz}$ ultrasound has been reported to promote chondrogenesis in human bone marrowderived MSCs when used alongside chondrogenic induction media containing TGF $\beta 3$ (Guha Thakurta et al., 2015). Photostimulation has also been shown to affect stem cell 
differentiation in induction media, as blue light at $455 \mathrm{~nm}$ and $470 \mathrm{~nm}$ maintained human bone marrow-derived MSC multipotency while red light at $656 \mathrm{~nm}$ promoted osteogenesis (Wilner, 2010). Biochemical and biophysical cues can be combined to modulate stem cell behaviour.

Figure 5. A: Electrical stimulation was delivered using carbon electrodes in an eight-channel “C-Pace EP” cell culture stimulator (IonOptix, Milton, MA, USA) (image adapted from CPace EP system brochure (Unknown, 2011)). B: Combined with differentiation media, unidirectional electric stimulation $(6.6 \mathrm{~V} / \mathrm{cm}, 1 \mathrm{~Hz}, 2 \mathrm{~ms}$ alternating polarity) produces hESC-derived cardiomyocytes with improved $\mathrm{Ca}^{2+}$ cycling, cytoskeletal organisation, elongated growth aligned with electrical stimulation direction (indicated by arrows), and cardiac-specific gene expression (image adapted from Chan et al. (Chan et al., 2013) and reprinted with permission from Springer). Red = human cardiac troponin- $\mathrm{T}$; Green $=$ sarcomeric alpha-actinin; Blue = nuclei.

The consequences of this combinational approach can be useful, but such studies may pose issues in establishing the role of biophysical factors in regulating stem cell behaviour. For example, growth factors found in Matrigel, commonly used to facilitate PSC attachment, have an influence on cell behaviour which may need to be considered when interpreting experiment results where Matrigel is used (Hughes et al., 2010; Vukicevic et al., 1992). Components of Matrigel, such as laminins, collagens and various other proteins including signalling molecules, dissolve at different rates from the solidified layer into the surrounding fluid, where they may act as soluble biomolecules to influence cell behaviour (Zhang et al., 
2006). Additionally, it has been reported that biophysical cues such as substrate topography can trigger cell signalling pathways distinct from those triggered by chemical signals, relating to a wide range of cellular processes (Dalby et al., 2007) but it is still unclear whether the pathways overlap or interact when biophysical and biochemical cues are used in combination, and to what extent. It is important to distinguish between the effects arising from biochemical cues and those from biophysical cues in order to clarify the exact influence these factors have on stem cells.

The effect of patterned chemical surfaces is another area of interest in manipulating stem cell morphology and phenotype. Kilian et al. compared differentiation of human bone marrowderived MSCs on sharp- and soft-edged two-dimensional fibronectin star shapes in the presence of a mixture of adipogenic and osteogenic soluble growth factors (Kilian et al., 2010). They found that cells grown on soft-edged patterns had lower intracellular tension and primarily differentiated into adipocytes, while cells on sharp-edged patterns had higher tension and mainly formed osteoblasts (Kilian et al., 2010). Adsorption of proteins like fibronectin to patterned or micro-textured PDMS surfaces has been used in biomaterial development for musculoskeletal tissue engineering from MSCs (Peterson and Papautsky, 2006). These studies have provided insights into cell signalling pathways and potential improvements in bioengineering.

\section{Conclusion and future prospects}

While biochemical stimulation has been firmly established as a method of culturing and manipulating stem cells, biophysical stimulation from substrates, such as topographical patterning and matrix stiffness, and external stimulation, such as mechanical loading and 
electrical stimulation, have the potential to vastly improve current stem cell differentiation techniques and tissue engineering technologies. Since these factors are all present in combination with chemical stimulation in native stem cell environments, they could be applied to create more advanced biomimetic environments in vitro to generate more mature and native-like cells for artificially engineered tissues. Physical stimulation like surface topography could improve prosthetics and artificial tissue replacement surgeries, where conventional biochemical approaches may be inaccessible in vivo. These biophysical cues could also be used as a tool to study cell behaviour in vitro, where the environment and surrounding factors can be more tightly controlled than in studies in vivo. Additionally, biochemical and biophysical cues could be combined to better manipulate stem cell behaviour, such as complete differentiation into mature somatic cell types. New cell culture tools using both these methods need to be developed. Biophysical stimulation and its effects on stem cells is an area of great potential for future practical applications.

Major challenges in the development of new regenerative therapies using stem cells include the difficulty of scaling up stem cell self-renewal and differentiation processes to sufficient levels, and the fact that current in vitro differentiation techniques are limited in efficiency and functional maturation of resultant cells. These existing methods can also be expensive, timeconsuming and difficult to control in terms of defining exact media chemical compositions, difficulties in sequential addition and removal of growth factors, and isolation or purification of desired cell types (Kingham and Oreffo, 2013; Lee et al., 2010). Exogenous soluble factors and animal-derived products can pose problems, particularly relating to contamination, for cell transplantation in clinical applications (Villa-Diaz et al., 2013). Biophysical cues could be the key to solving these issues (Kingham and Oreffo, 2013). The development of nextgeneration cell culture protocols combining physical and chemical stimulation will allow more vigorous study of stem cell behaviour. However, the main priority of future research 
should be to clarify the influence of biophysical stimulation on stem cell self-renewal, phenotype and directed differentiation, and establish reliable methods for its use in stem cell culture and cell therapy.

\section{Acknowledgments}

The Australian Research Council (ARC) is acknowledged for providing the Discovery Early

Career Researcher Award (DECRA) for P.-Y. Wang. This work is supported by DECRA and the Biomedical Research Victoria for the Undergraduate Research Opportunities Program (UROP).

\section{References}

Abbasnia K, Ghanbari A, Abedian M, Ghanbari A, Sharififar S, Azari H. 2015. The effects of repetitive transcranial magnetic stimulation on proliferation and differentiation of neural stem cells. Anat. Cell Biol. 48:104-13.

Aguilar JS, Begum AN, Alvarez J, Zhang X, Hong Y, Hao J. 2015. Directed cardiomyogenesis of human pluripotent stem cells by modulating Wnt/ $\beta$-catenin and BMP signalling with small molecules. Biochem. J. 469:235-41.

Agulnick AD, Ambruzs DM, Moorman MA, Bhoumik A, Cesario RM, Payne JK, Kelly JR, Haakmeester C, Srijemac R, Wilson AZ, Kerr J, Frazier MA, Kroon EJ, D' Amour KA. 2015. Insulin-producing endocrine cells differentiated in vitro from human embryonic stem cells function in macroencapsulation devices in vivo. Stem Cells Transl. Med. 4:1214-22.

Ahsan T, Nerem RM. 2010. Fluid shear stress promotes an endothelial-like phenotype during the early differentiation of embryonic stem cells. Tissue Eng. Part A 16:3547-53.

Akhavan O, Ghaderi E, Shirazian S a. 2015. Near infrared laser stimulation of human neural stem cells into neurons on graphene nanomesh semiconductors. Colloids Surf. B. Biointerfaces 126:313-21.

Akhmanova M, Osidak E, Domogatsky S, Rodin S, Domogatskaya A. 2015. Physical, spatial, and molecular aspects of extracellular matrix of in vivo niches and artificial scaffolds relevant to stem cells research. Stem Cells Int. 2015:167025.

Alberti K, Davey RE, Onishi K, George S, Salchert K, Seib FP, Bornhäuser M, Pompe T, Nagy A, Werner C, Zandstra PW. 2008. Functional immobilization of signaling proteins enables control of stem cell fate. Nat. Methods 5:645-50.

Ambasudhan R, Dolatabadi N, Nutter A, Masliah E, Mckercher SR, Lipton SA. 2014. Potential for cell therapy in Parkinson's disease using genetically programmed human 
embryonic stem cell-derived neural progenitor cells. J. Comp. Neurol. 522:2845-56.

Arbab AS, Yocum GT, Rad AM, Khakoo AY, Fellowes V, Read EJ, Frank JA. 2005. Labeling of cells with ferumoxides-protamine sulfate complexes does not inhibit function or differentiation capacity of hematopoietic or mesenchymal stem cells. NMR Biomed. 18:553-9.

Bacakova L, Filova E, Parizek M, Ruml T, Svorcik V. 2011. Modulation of cell adhesion, proliferation and differentiation on materials designed for body implants. Biotechnol. Adv. 29:739-67.

Bai L, Caplan A, Lennon D, Miller RH. 2007. Human mesenchymal stem cells signals regulate neural stem cell fate. Neurochem. Res. 32:353-62.

Baxter M, Withey S, Harrison S, Segeritz C-P, Zhang F, Atkinson-Dell R, Rowe C, Gerrard DT, Sison-Young R, Jenkins R, Henry J, Berry AA, Mohamet L, Best M, Fenwick SW, Malik H, Kitteringham NR, Goldring CE, Piper Hanley K, Vallier L, Hanley NA. 2015. Phenotypic and functional analyses show stem cell-derived hepatocyte-like cells better mimic fetal rather than adult hepatocytes. J. Hepatol. 62:581-9.

Bhatia SN, Underhill GH, Zaret KS, Fox IJ. 2014. Cell and tissue engineering for liver disease. Sci. Transl. Med. 6:245sr2.

Brzoska M, Geiger H, Gauer S, Baer P. 2005. Epithelial differentiation of human adipose tissue-derived adult stem cells. Biochem. Biophys. Res. Commun. 330:142-50.

Budniatzky I, Gepstein L. 2014. Concise review: reprogramming strategies for cardiovascular regenerative medicine: from induced pluripotent stem cells to direct reprogramming. Stem Cells Transl. Med. 3:448-57.

Burridge PW, Matsa E, Shukla P, Lin ZC, Churko JM, Ebert AD, Lan F, Diecke S, Huber B, Mordwinkin NM, Plews JR, Abilez OJ, Cui B, Gold JD, Wu JC. 2014. Chemically defined generation of human cardiomyocytes. Nat. Methods 11:855-60.

Cameron IL, Hardman WE, Winters WD, Zimmerman S, Zimmerman AM. 1993. Environmental magnetic fields: influences on early embryogenesis. J. Cell. Biochem. 51:417-25.

Cha KJ, Hong JM, Cho D-W, Kim DS. 2013. Enhanced osteogenic fate and function of MC3T3-E1 cells on nanoengineered polystyrene surfaces with nanopillar and nanopore arrays. Biofabrication 5:025007.

Chambers SM, Fasano CA, Papapetrou EP, Tomishima M, Sadelain M, Studer L. 2009. Highly efficient neural conversion of human ES and iPS cells by dual inhibition of SMAD signaling. Nat. Biotechnol. 27:275-80.

Chambers SM, Mica Y, Lee G, Studer L, Tomishima MJ. 2016. Dual-SMAD Inhibition/WNT Activation-based methods to induce neural crest and derivatives from human pluripotent stem cells. Methods Mol. Biol. 1307:329-43.

Chambers SM, Qi Y, Mica Y, Lee G, Zhang X-J, Niu L, Bilsland J, Cao L, Stevens E, Whiting P, Shi S-H, Studer L. 2012. Combined small-molecule inhibition accelerates developmental timing and converts human pluripotent stem cells into nociceptors. Nat. Biotechnol. 30:715-20.

Chan Y-C, Ting S, Lee Y-K, Ng K-M, Zhang J, Chen Z, Siu C-W, Oh SKW, Tse H-F. 2013. Electrical stimulation promotes maturation of cardiomyocytes derived from human 
embryonic stem cells. J. Cardiovasc. Transl. Res. 6:989-99.

Chen G, Gulbranson DR, Hou Z, Bolin JM, Ruotti V, Probasco MD, Smuga-Otto K, Howden SE, Diol NR, Propson NE, Wagner R, Lee GO, Antosiewicz-Bourget J, Teng JMC, Thomson JA. 2011. Chemically defined conditions for human iPSC derivation and culture. Nat. Methods 8:424-9.

Chiu C-Y, Tsai T-L, Vanderby R, Bradica G, Lou S-L, Li W-J. 2015. Osteoblastogenesis of mesenchymal stem cells in 3-D culture enhanced by low-intensity pulsed ultrasound through soluble receptor activator of nuclear factor kappa B ligand. Ultrasound Med. Biol. 41:1842-52.

Cho H, Seo Y-K, Yoon H-H, Kim S-C, Kim S-M, Song K-Y, Park J-K. 2012. Neural stimulation on human bone marrow-derived mesenchymal stem cells by extremely low frequency electromagnetic fields. Biotechnol. Prog. 28:1329-35.

Chojnacki A, Weiss S. 2008. Production of neurons, astrocytes and oligodendrocytes from mammalian CNS stem cells. Nat. Protoc. 3:935-40.

Chuah YJ, Kuddannaya S, Lee MHA, Zhang Y, Kang Y. 2015. The effects of poly(dimethylsiloxane) surface silanization on the mesenchymal stem cell fate. Biomater. Sci. 3:383-90.

Claes L, Willie B. 2007. The enhancement of bone regeneration by ultrasound. Prog. Biophys. Mol. Biol. 93:384-98.

Cook D, Genever P. 2013. Regulation of mesenchymal stem cell differentiation. Adv. Exp. Med. Biol. 786:213-29.

Cutler MJ, Jeyaraj D, Rosenbaum DS. 2011. Cardiac electrical remodeling in health and disease. Trends Pharmacol. Sci. 32:174-80.

D’Amour K a, Bang AG, Eliazer S, Kelly OG, Agulnick AD, Smart NG, Moorman MA, Kroon E, Carpenter MK, Baetge EE. 2006. Production of pancreatic hormoneexpressing endocrine cells from human embryonic stem cells. Nat. Biotechnol. 24:1392401.

Dalby MJ, Gadegaard N, Oreffo ROC. 2014. Harnessing nanotopography and integrin-matrix interactions to influence stem cell fate. Nat. Mater. 13:558-69.

Dalby MJ, Gadegaard N, Tare R, Andar A, Riehle MO, Herzyk P, Wilkinson CDW, Oreffo ROC. 2007. The control of human mesenchymal cell differentiation using nanoscale symmetry and disorder. Nat. Mater. 6:997-1003.

Damien P, Allan DS. 2015. Regenerative Therapy and Immune Modulation Using Umbilical Cord Blood-Derived Cells. Biol. Blood Marrow Transplant. 21:1545-54.

Dan P, Velot É, Decot V, Menu P. 2015. The role of mechanical stimuli in the vascular differentiation of mesenchymal stem cells. J. Cell Sci. 128:2415-22.

Dånmark S, Finne-Wistrand A, Albertsson A-C, Patarroyo M, Mustafa K. 2012. Integrinmediated adhesion of human mesenchymal stem cells to extracellular matrix proteins adsorbed to polymer surfaces. Biomed. Mater. 7:035011.

Downing TL, Soto J, Morez C, Houssin T, Fritz A, Yuan F, Chu J, Patel S, Schaffer D V, Li S. 2013. Biophysical regulation of epigenetic state and cell reprogramming. Nat. Mater. 12:1154-62. 
Duffy CRE, Zhang R, How S-E, Lilienkampf A, De Sousa P a., Bradley M. 2014. Long term mesenchymal stem cell culture on a defined synthetic substrate with enzyme free passaging. Biomaterials 35:5998-6005.

Edalat F, Sheu I, Manoucheri S, Khademhosseini A. 2012. Material strategies for creating artificial cell-instructive niches. Curr. Opin. Biotechnol. 23:820-5.

Efthymiou AG, Chen G, Rao M, Chen G, Boehm M. 2014. Self-renewal and cell lineage differentiation strategies in human embryonic stem cells and induced pluripotent stem cells. Expert Opin. Biol. Ther. 14:1333-44.

Engler AJ, Carag-Krieger C, Johnson CP, Raab M, Tang H-Y, Speicher DW, Sanger JW, Sanger JM, Discher DE. 2008. Embryonic cardiomyocytes beat best on a matrix with heart-like elasticity: scar-like rigidity inhibits beating. J. Cell Sci. 121:3794-802.

Engler AJ, Sen S, Sweeney HL, Discher DE. 2006. Matrix elasticity directs stem cell lineage specification. Cell 126:677-89.

Epifanio M, Inguva S, Kitching M, Mosnier J-P, Marsili E. 2015. Effects of atmospheric air plasma treatment of graphite and carbon felt electrodes on the anodic current from Shewanella attached cells. Bioelectrochemistry 106:186-93.

Fayol D, Luciani N, Lartigue L, Gazeau F, Wilhelm C. 2013. Managing magnetic nanoparticle aggregation and cellular uptake: a precondition for efficient stem-cell differentiation and MRI tracking. Adv. Healthc. Mater. 2:313-25.

Feng J-F, Liu J, Zhang X-Z, Zhang L, Jiang J-Y, Nolta J, Zhao M. 2012. Guided migration of neural stem cells derived from human embryonic stem cells by an electric field. Stem Cells 30:349-355.

Fonoudi H, Ansari H, Abbasalizadeh S, Larijani MR, Kiani S, Hashemizadeh S, Zarchi AS, Bosman A, Blue GM, Pahlavan S, Perry M, Orr Y, Mayorchak Y, Vandenberg J, Talkhabi M, Winlaw DS, Harvey RP, Aghdami N, Baharvand H. 2015. A universal and robust integrated platform for the scalable production of human cardiomyocytes from pluripotent stem cells. Stem Cells Transl. Med. 4:1482-94.

Forte G, Pagliari S, Ebara M, Uto K, Tam JK Van, Romanazzo S, Escobedo-Lucea C, Romano E, Di Nardo P, Traversa E, Aoyagi T. 2012. Substrate stiffness modulates gene expression and phenotype in neonatal cardiomyocytes in vitro. Tissue Eng. Part A 18: $1837-48$.

Gao Y, Bai C, Wang K, Sun B, Guan W, Zheng D. 2014. All-trans retinoic acid promotes nerve cell differentiation of yolk sac-derived mesenchymal stem cells. Appl. Biochem. Biotechnol. 174:682-92.

Gattazzo F, Urciuolo A, Bonaldo P. 2014. Extracellular matrix: a dynamic microenvironment for stem cell niche. Biochim. Biophys. Acta 1840:2506-19.

Geuss LR, Suggs LJ. 2013. Making cardiomyocytes: how mechanical stimulation can influence differentiation of pluripotent stem cells. Biotechnol. Prog. 29:1089-96.

Gong Z, Niklason LE. 2008. Small-diameter human vessel wall engineered from bone marrow-derived mesenchymal stem cells (hMSCs). FASEB J. 22:1635-48.

Griffin MF, Butler PE, Seifalian AM, Kalaskar DM. 2015. Control of stem cell fate by engineering their micro and nanoenvironment. World J. Stem Cells 7:37-50. 
Guha Thakurta S, Budhiraja G, Subramanian A. 2015. Growth factor and ultrasound-assisted bioreactor synergism for human mesenchymal stem cell chondrogenesis. J. Tissue Eng. 6:2041731414566529.

Guvendiren M, Burdick J a. 2012. Stiffening hydrogels to probe short- and long-term cellular responses to dynamic mechanics. Nat. Commun. 3:792.

Hadjizadeh A, Doillon CJ. 2010. Directional migration of endothelial cells towards angiogenesis using polymer fibres in a 3D co-culture system. J. Tissue Eng. Regen. Med. 4:524-31.

Hao J, Zhang Y, Jing D, Shen Y, Tang G, Huang S, Zhao Z. 2015. Mechanobiology of mesenchymal stem cells: Perspective into mechanical induction of MSC fate. Acta Biomater. 20:1-9.

Haragopal H, Yu D, Zeng X, Kim S-W, Han I-B, Ropper AE, Anderson JE, Teng YD. 2015. Stemness enhancement of human neural stem cells following bone marrow MSC coculture. Cell Transplant. 24:645-59.

Hartman ME, Dai D-F, Laflamme M a. 2015. Human pluripotent stem cells: Prospects and challenges as a source of cardiomyocytes for in vitro modeling and cell-based cardiac repair. Adv. Drug Deliv. Rev.

Haudenschild AK, Hsieh AH, Kapila S, Lotz JC. 2009. Pressure and distortion regulate human mesenchymal stem cell gene expression. Ann. Biomed. Eng. 37:492-502.

Hazeltine LB, Badur MG, Lian X, Das A, Han W, Palecek SP. 2014. Temporal impact of substrate mechanics on differentiation of human embryonic stem cells to cardiomyocytes. Acta Biomater. 10:604-12.

Hazeltine LB, Selekman J a., Palecek SP. 2013. Engineering the human pluripotent stem cell microenvironment to direct cell fate. Biotechnol. Adv. 31:1002-19.

Higuchi A, Ling Q-D, Kumar SS, Chang Y, Kao T-C, Munusamy M a., Alarfaj A a., Hsu ST, Umezawa A. 2014a. External stimulus-responsive biomaterials designed for the culture and differentiation of ES, iPS, and adult stem cells. Prog. Polym. Sci. 39:15851613.

Higuchi S, Watanabe TM, Kawauchi K, Ichimura T, Fujita H. 2014b. Culturing of mouse and human cells on soft substrates promote the expression of stem cell markers. J. Biosci. Bioeng. 117:749-55.

Hirt MN, Boeddinghaus J, Mitchell A, Schaaf S, Börnchen C, Müller C, Schulz H, Hubner N, Stenzig J, Stoehr A, Neuber C, Eder A, Luther PK, Hansen A, Eschenhagen T. 2014. Functional improvement and maturation of rat and human engineered heart tissue by chronic electrical stimulation. J. Mol. Cell. Cardiol. 74:151-61.

Hoogduijn MJ, Betjes MGH, Baan CC. 2014. Mesenchymal stromal cells for organ transplantation: different sources and unique characteristics? Curr. Opin. Organ Transplant. 19:41-6.

Hu B-Y, Du Z-W, Zhang S-C. 2009. Differentiation of human oligodendrocytes from pluripotent stem cells. Nat. Protoc. 4:1614-22.

Huang P, He Z, Ji S, Sun H, Xiang D, Liu C, Hu Y, Wang X, Hui L. 2011. Induction of functional hepatocyte-like cells from mouse fibroblasts by defined factors. Nature 475:386-9. 
Hughes CS, Postovit LM, Lajoie GA. 2010. Matrigel: a complex protein mixture required for optimal growth of cell culture. Proteomics 10:1886-90.

Hulsman M, Hulshof F, Unadkat H, Papenburg BJ, Stamatialis DF, Truckenmüller R, van Blitterswijk C, de Boer J, Reinders MJT. 2015. Analysis of high-throughput screening reveals the effect of surface topographies on cellular morphology. Acta Biomater. 15:29-38.

Hwang J-H, Byun MR, Kim AR, Kim KM, Cho HJ, Lee YH, Kim J, Jeong MG, Hwang ES, Hong J-H. 2015. Extracellular matrix stiffness regulates osteogenic differentiation through MAPK activation. PLoS One 10:e0135519.

Ji L, LaPointe VLS, Evans ND, Stevens MM. 2012. Changes in embryonic stem cell colony morphology and early differentiation markers driven by colloidal crystal topographical cues. Eur. Cell. Mater. 23:135-46.

Jin G, Yang G-H, Kim G. 2015. Tissue engineering bioreactor systems for applying physical and electrical stimulations to cells. J. Biomed. Mater. Res. B. Appl. Biomater. 103:93548 .

Johnson KE, Makanji Y, Temple-Smith P, Kelly EK, Barton PA, Al-Musawi SL, Mueller TD, Walton KL, Harrison CA. 2015. Biological activity and in vivo half-life of proactivin A in male rats. Mol. Cell. Endocrinol.

Jung S, Panchalingam KM, Rosenberg L, Behie LA. 2012. Ex vivo expansion of human mesenchymal stem cells in defined serum-free media. Stem Cells Int. 2012:123030.

Kabiri M, Soleimani M, Shabani I, Futrega K, Ghaemi N, Ahvaz HH, Elahi E, Doran MR. 2012. Neural differentiation of mouse embryonic stem cells on conductive nanofiber scaffolds. Biotechnol. Lett. 34:1357-65.

Kane NM, Meloni M, Spencer HL, Craig M a., Strehl R, Milligan G, Houslay MD, Mountford JC, Emanueli C, Baker AH. 2010. Derivation of endothelial cells from human embryonic stem cells by directed differentiation: analysis of microRNA and angiogenesis in vitro and in vivo. Arterioscler. Thromb. Vasc. Biol. 30:1389-97.

Kang J, Park HM, Kim YW, Kim YH, Varghese S, Seok HK, Kim YG, Kim SH. 2014. Control of mesenchymal stem cell phenotype and differentiation depending on cell adhesion mechanism. Eur. Cell. Mater. 28:387-403.

Kang KS, Hong JM, Kang J a, Rhie J-W, Cho D-W. 2013a. Osteogenic differentiation of human adipose-derived stem cells can be accelerated by controlling the frequency of continuous ultrasound. J. Ultrasound Med. 32:1461-70.

Kang KS, Hong JM, Kang J a, Rhie J-W, Jeong YH, Cho D-W. 2013b. Regulation of osteogenic differentiation of human adipose-derived stem cells by controlling electromagnetic field conditions. Exp. Mol. Med. 45:e6.

Keung AJ, Asuri P, Kumar S, Schaffer D V. 2012. Soft microenvironments promote the early neurogenic differentiation but not self-renewal of human pluripotent stem cells. Integr. Biol. (Camb). 4:1049-58.

Kilian K a, Bugarija B, Lahn BT, Mrksich M. 2010. Geometric cues for directing the differentiation of mesenchymal stem cells. Proc. Natl. Acad. Sci. U. S. A. 107:4872-7.

Kim M-O, Jung H, Kim S-C, Park J-K, Seo Y-K. 2015. Electromagnetic fields and nanomagnetic particles increase the osteogenic differentiation of human bone marrow- 
derived mesenchymal stem cells. Int. J. Mol. Med. 35:153-60.

Kimbrel E a., Lanza R. 2015. Current status of pluripotent stem cells: moving the first therapies to the clinic. Nat. Rev. Drug Discov. 14:681-692.

Kingham E, Oreffo ROC. 2013. Embryonic and induced pluripotent stem cells: understanding, creating, and exploiting the nano-niche for regenerative medicine. ACS Nano 7:1867-81.

Kingham E, White K, Gadegaard N, Dalby MJ, Oreffo ROC. 2013. Nanotopographical cues augment mesenchymal differentiation of human embryonic stem cells. Small 9:2140-51.

Koegler P, Clayton A, Thissen H, Santos GNC, Kingshott P. 2012. The influence of nanostructured materials on biointerfacial interactions. Adv. Drug Deliv. Rev. 64:1820 39.

Kosovsky M. 2013. Culture Conditions and ECM Surfaces utilized for the investigation of stem cell differentiation. Corning Inc.:1-16.

Kostura L, Kraitchman DL, Mackay AM, Pittenger MF, Bulte JWM. 2004. Feridex labeling of mesenchymal stem cells inhibits chondrogenesis but not adipogenesis or osteogenesis. NMR Biomed. 17:513-7.

Krencik R, Weick JP, Liu Y, Zhang Z-J, Zhang S-C. 2011. Specification of transplantable astroglial subtypes from human pluripotent stem cells. Nat. Biotechnol. 29:528-34.

Kroon E, Martinson LA, Kadoya K, Bang AG, Kelly OG, Eliazer S, Young H, Richardson M, Smart NG, Cunningham J, Agulnick AD, D'Amour K a, Carpenter MK, Baetge EE. 2008. Pancreatic endoderm derived from human embryonic stem cells generates glucose-responsive insulin-secreting cells in vivo. Nat. Biotechnol. 26:443-52.

Kshitiz, Park J, Kim P, Helen W, Engler AJ, Levchenko A, Kim D-H. 2012. Control of stem cell fate and function by engineering physical microenvironments. Integr. Biol. (Camb). 4:1008-18.

Kuddannaya S, Chuah YJ, Lee MHA, Menon N V, Kang Y, Zhang Y. 2013. Surface chemical modification of poly(dimethylsiloxane) for the enhanced adhesion and proliferation of mesenchymal stem cells. ACS Appl. Mater. Interfaces 5:9777-84.

Kulangara K, Yang J, Chellappan M, Yang Y, Leong KW. 2014. Nanotopography alters nuclear protein expression, proliferation and differentiation of human mesenchymal stem/stromal cells. PLoS One 9:e114698.

Kuo Y-C, Chang T-H, Hsu W-T, Zhou J, Lee H-H, Hui-Chun Ho J, Chien S, Kuang-Sheng O. 2015. Oscillatory shear stress mediates directional reorganization of actin cytoskeleton and alters differentiation propensity of mesenchymal stem cells. Stem Cells 33:429-442.

Kushibiki T, Awazu K. 2009. Blue laser irradiation enhances extracellular calcification of primary mesenchymal stem cells. Photomed. Laser Surg. 27:493-8.

Laflamme MA, Chen KY, Naumova A V, Muskheli V, Fugate JA, Dupras SK, Reinecke H, Xu C, Hassanipour M, Police S, O’Sullivan C, Collins L, Chen Y, Minami E, Gill EA, Ueno S, Yuan C, Gold J, Murry CE. 2007. Cardiomyocytes derived from human embryonic stem cells in pro-survival factors enhance function of infarcted rat hearts. Nat. Biotechnol. 25:1015-24. 
Lapointe VLS, Fernandes AT, Bell NC, Stellacci F, Stevens MM. 2013. Nanoscale topography and chemistry affect embryonic stem cell self-renewal and early differentiation. Adv. Healthc. Mater. 2:1644-50.

Lee J, Blaber M. 2009. The Interaction between Thermodynamic Stability and Buried Free Cysteines in Regulating the Functional Half-Life of Fibroblast Growth Factor-1. J. Mol. Biol. 393:113-127.

Lee MR, Kwon KW, Jung H, Kim HN, Suh KY, Kim K, Kim K-S. 2010. Direct differentiation of human embryonic stem cells into selective neurons on nanoscale ridge/groove pattern arrays. Biomaterials 31:4360-6.

Levesque MJ, Nerem RM. 1985. The elongation and orientation of cultured endothelial cells in response to shear stress. J. Biomech. Eng. 107:341-7.

Li J, Zhu L, Qu X, Li J, Lin R, Liao L, Wang J, Wang S, Xu Q, Zhao RC. 2013. Stepwise differentiation of human adipose-derived mesenchymal stem cells toward definitive endoderm and pancreatic progenitor cells by mimicking pancreatic development in vivo. Stem Cells Dev. 22:1576-87.

Li R, Liang L, Dou Y, Huang Z, Mo H, Wang Y, Yu B. 2015. Mechanical strain regulates osteogenic and adipogenic differentiation of bone marrow mesenchymal stem cells. Biomed Res. Int. 2015:873251.

Li X, Chu JS, Yang L, Li S. 2012. Anisotropic effects of mechanical strain on neural crest stem cells. Ann. Biomed. Eng. 40:598-605.

Lian X, Hsiao C, Wilson G, Zhu K, Hazeltine LB, Azarin SM, Raval KK, Zhang J, Kamp TJ, Palecek SP. 2012. Robust cardiomyocyte differentiation from human pluripotent stem cells via temporal modulation of canonical Wnt signaling. Proc. Natl. Acad. Sci. U. S. A. 109:E1848-57.

Liao X, Xie G-H, Liu H-W, Cheng B, Li S-H, Xie S, Xiao L-L, Fu X-B. 2014. Helium-neon laser irradiation promotes the proliferation and migration of human epidermal stem cells in vitro: proposed mechanism for enhanced wound re-epithelialization. Photomed. Laser Surg. 32:219-25.

Liu Y-S, Lee OK. 2013. In search of the pivot point of mechanotransduction: Mechanosensing of stem cells. Cell Transplant. 23:1-11.

Lu J, Hou R, Booth CJ, Yang S-H, Snyder M. 2006. Defined culture conditions of human embryonic stem cells. Proc. Natl. Acad. Sci. U. S. A. 103:5688-93.

De Luca AC, Zink M, Weidt A, Mayr SG, Markaki AE. 2015. Effect of microgrooved surface topography on osteoblast maturation and protein adsorption. J. Biomed. Mater. Res. Part A:n/a-n/a.

Luna JI, Ciriza J, Garcia-Ojeda ME, Kong M, Herren A, Lieu DK, Li R a, Fowlkes CC, Khine M, McCloskey KE. 2011. Multiscale biomimetic topography for the alignment of neonatal and embryonic stem cell-derived heart cells. Tissue Eng. Part C. Methods 17:579-88.

Luo W, Jones SR, Yousaf MN. 2008. Geometric Control of Stem Cell Differentiation Rate on Surfaces. Langmuir 24:12129-12133.

Lv Y, Zhao P, Chen G, Sha Y, Yang L. 2013. Effects of low-intensity pulsed ultrasound on cell viability, proliferation and neural differentiation of induced pluripotent stem cells- 
derived neural crest stem cells. Biotechnol. Lett. 35:2201-12.

Ma Q, Deng P, Zhu G, Liu C, Zhang L, Zhou Z, Luo X, Li M, Zhong M, Yu Z, Chen C, Zhang Y. 2014. Extremely low-frequency electromagnetic fields affect transcript levels of neuronal differentiation-related genes in embryonic neural stem cells. PLoS One 9:e90041.

Ma X, Zhang X, Jia Y, Zu S, Han S, Xiao D, Sun H, Wang Y. 2013. Dexamethasone induces osteogenesis via regulation of hedgehog signalling molecules in rat mesenchymal stem cells. Int. Orthop. 37:1399-404.

Macrí-Pellizzeri L, Pelacho B, Sancho A, Iglesias-García O, Simón-Yarza AM, SorianoNavarro M, González-Granero S, García-Verdugo JM, De-Juan-Pardo EM, Prosper F. 2015. Substrate stiffness and composition specifically direct differentiation of induced pluripotent stem cells. Tissue Eng. Part A 21:1633-41.

Mallanna SK, Duncan S a. 2013. Differentiation of hepatocytes from pluripotent stem cells. Curr. Protoc. Stem Cell Biol. 26:Unit 1G.4.

Marks AR. 2013. Calcium cycling proteins and heart failure: mechanisms and therapeutics. $J$. Clin. Invest. 123:46-52.

McMurray RJ, Gadegaard N, Tsimbouri PM, Burgess K V, McNamara LE, Tare R, Murawski K, Kingham E, Oreffo ROC, Dalby MJ. 2011. Nanoscale surfaces for the long-term maintenance of mesenchymal stem cell phenotype and multipotency. Nat. Mater. 10:637-44.

Mica Y, Lee G, Chambers SM, Tomishima MJ, Studer L. 2013. Modeling neural crest induction, melanocyte specification, and disease-related pigmentation defects in hESCs and patient-specific iPSCs. Cell Rep. 3:1140-52.

Minardi S, Taraballi F, Pandolfi L, Tasciotti E. 2016. Patterning biomaterials for the spatiotemporal delivery of bioactive molecules. Front. Bioeng. Biotechnol. 4:1-7.

Mitchell AC, Briquez PS, Hubbell JA, Cochran JR. 2016. Engineering growth factors for regenerative medicine applications. Acta Biomater. 30:1-12.

Mummery CL, Zhang J, Ng ES, Elliott DA, Elefanty AG, Kamp TJ. 2012. Differentiation of human embryonic stem cells and induced pluripotent stem cells to cardiomyocytes: a methods overview. Circ. Res. 111:344-58.

Murphy WL, McDevitt TC, Engler AJ. 2014. Materials as stem cell regulators. Nat. Mater. 13:547-57.

Nagaoka M, Si-Tayeb K, Akaike T, Duncan SA. 2010. Culture of human pluripotent stem cells using completely defined conditions on a recombinant E-cadherin substratum. BMC Dev. Biol. 10:60.

Narvaez CJ, Simmons KM, Brunton J, Salinero A, Chittur S V, Welsh JE. 2013. Induction of STEAP4 correlates with 1,25-dihydroxyvitamin D3 stimulation of adipogenesis in mesenchymal progenitor cells derived from human adipose tissue. J. Cell. Physiol. 228:2024-36.

Nava MM, Raimondi MT, Pietrabissa R. 2012. Controlling self-renewal and differentiation of stem cells via mechanical cues. J. Biomed. Biotechnol. 2012:797410.

Nikkhah M, Edalat F, Manoucheri S, Khademhosseini A. 2012. Engineering microscale 
topographies to control the cell-substrate interface. Biomaterials 33:5230-46.

Nsiah B a, Ahsan T, Griffiths S, Cooke M, Nerem RM, McDevitt TC. 2014. Fluid shear stress pre-conditioning promotes endothelial morphogenesis of embryonic stem cells within embryoid bodies. Tissue Eng. Part A 20:954-65.

Nune KC, Misra RDK. 2014. Pre-adsorption of protein on electrochemically grooved nanostructured stainless steel implant and relationship to cellular activity. J. Biomed. Nanotechnol. 10:1320-35.

Pagliuca FW, Millman JR, Gürtler M, Segel M, Van Dervort A, Ryu JH, Peterson QP, Greiner D, Melton DA. 2014. Generation of functional human pancreatic $\beta$ cells in vitro. Cell 159:428-39.

Park JS, Yang HN, Woo DG, Jeon SY, Do H-J, Huh S-H, Kim N-H, Kim J-H, Park K-H. 2012. Exogenous Nurr1 gene expression in electrically-stimulated human MSCs and the induction of neurogenesis. Biomaterials 33:7300-7308.

Park S, Im G-I. 2015. Stem cell responses to nanotopography. J. Biomed. Mater. Res. A 103:1238-45.

Pegueroles M, Aparicio C, Bosio M, Engel E, Gil FJ, Planell JA, Altankov G. 2010. Spatial organization of osteoblast fibronectin matrix on titanium surfaces: Effects of roughness, chemical heterogeneity and surface energy. Acta Biomater. 6:291-301.

Pelttari K, Steck E, Richter W. 2008. The use of mesenchymal stem cells for chondrogenesis. Injury 39:58-65.

de Peppo GM, Marolt D. 2013. Modulating the biochemical and biophysical culture environment to enhance osteogenic differentiation and maturation of human pluripotent stem cell-derived mesenchymal progenitors. Stem Cell Res. Ther. 4:106.

Peterson ETK, Papautsky I. 2006. Microtextured polydimethylsiloxane substrates for culturing mesenchymal stem cells. Methods Mol. Biol. 321:179-97.

Pires F, Ferreira Q, Rodrigues CA V, Morgado J, Ferreira FC. 2015. Neural stem cell differentiation by electrical stimulation using a cross-linked PEDOT substrate: Expanding the use of biocompatible conjugated conductive polymers for neural tissue engineering. Biochim. Biophys. Acta 1850:1158-68.

Pittenger MF, Mackay AM, Beck SC, Jaiswal RK, Douglas R, Mosca JD, Moorman MA, Simonetti DW, Craig S, Marshak DR. 1999. Multilineage potential of adult human mesenchymal stem cells. Science 284:143-7.

Porcellini A. 2009. Regenerative medicine: a review. Rev. Bras. Hematol. Hemoter. 31:6366.

Qian L, Saltzman WM. 2004. Improving the expansion and neuronal differentiation of mesenchymal stem cells through culture surface modification. Biomaterials 25:1331-7.

Rao C, Prodromakis T, Kolker L, Chaudhry U a R, Trantidou T, Sridhar A, Weekes C, Camelliti P, Harding SE, Darzi A, Yacoub MH, Athanasiou T, Terracciano CM. 2013. The effect of microgrooved culture substrates on calcium cycling of cardiac myocytes derived from human induced pluripotent stem cells. Biomaterials 34:2399-411.

Re'em T, Tsur-Gang O, Cohen S. 2010. The effect of immobilized RGD peptide in macroporous alginate scaffolds on TGFbeta1-induced chondrogenesis of human 
mesenchymal stem cells. Biomaterials 31:6746-55.

Reimer A, Vasilevich A, Hulshof F, Viswanathan P, van Blitterswijk CA, de Boer J, Watt FM. 2016. Scalable topographies to support proliferation and Oct4 expression by human induced pluripotent stem cells. Sci. Rep. 6:18948.

Rezania A, Bruin JE, Arora P, Rubin A, Batushansky I, Asadi A, O’Dwyer S, Quiskamp N, Mojibian M, Albrecht T, Yang YHC, Johnson JD, Kieffer TJ. 2014. Reversal of diabetes with insulin-producing cells derived in vitro from human pluripotent stem cells. Nat. Biotechnol. 32:1121-33.

Robertson MJ, Gip P, Schaffer D V. 2008. Neural stem cell engineering: directed differentiation of adult and embryonic stem cells into neurons. Front. Biosci. 13:21-50.

Rørth P. 2011. Whence directionality: guidance mechanisms in solitary and collective cell migration. Dev. Cell 20:9-18.

Ross CA, Akimov SS. 2014. Human-induced pluripotent stem cells: potential for neurodegenerative diseases. Hum. Mol. Genet. 23:R17-26.

Rostovskaya M, Bredenkamp N, Smith A. 2015. Towards consistent generation of pancreatic lineage progenitors from human pluripotent stem cells. Philos. Trans. R. Soc. Lond. B. Biol. Sci. 370.

Rowland TJ, Miller LM, Blaschke AJ, Doss EL, Bonham AJ, Hikita ST, Johnson L V, Clegg DO. 2010. Roles of integrins in human induced pluripotent stem cell growth on Matrigel and vitronectin. Stem Cells Dev. 19:1231-40.

Russo L, Russo T, Battocchio C, Taraballi F, Gloria A, D'Amora U, De Santis R, Polzonetti G, Nicotra F, Ambrosio L, Cipolla L. 2015. Galactose grafting on poly( $\varepsilon$-caprolactone) substrates for tissue engineering: A preliminary study. Carbohydr. Res. 405:39-46.

Saha S, Ji L, de Pablo JJ, Palecek SP. 2006. Inhibition of human embryonic stem cell differentiation by mechanical strain. J. Cell. Physiol. 206:126-37.

Salerno M, Caneva-Soumetz F, Pastorino L, Patra N, Diaspro A, Ruggiero C. 2013. Adhesion and proliferation of osteoblast-like cells on anodic porous alumina substrates with different morphology. IEEE Trans. Nanobioscience 12:106-11.

Santiago LY, Nowak RW, Peter Rubin J, Marra KG. 2006. Peptide-surface modification of poly(caprolactone) with laminin-derived sequences for adipose-derived stem cell applications. Biomaterials 27:2962-9.

Schulz TC. 2015. Concise Review: Manufacturing of pancreatic endoderm cells for clinical trials in type 1 diabetes. Stem Cells Transl. Med. 4:927-31.

Schwartz RE, Fleming HE, Khetani SR, Bhatia SN. 2014. Pluripotent stem cell-derived hepatocyte-like cells. Biotechnol. Adv. 32:504-13.

Sia J, Sun R, Chu J, Li S. 2016. Dynamic culture improves cell reprogramming efficiency. Biomaterials 92:36-45.

Somoza RA, Welter JF, Correa D, Caplan AI. 2014. Chondrogenic differentiation of mesenchymal stem cells: challenges and unfulfilled expectations. Tissue Eng. Part B. Rev. 20:596-608.

Sridharan I, Kim T, Wang R. 2009. Adapting collagen/CNT matrix in directing hESC differentiation. Biochem. Biophys. Res. Commun. 381:508-12. 
Srikanth P, Young-Pearse TL. 2014. Stem cells on the brain: modeling neurodevelopmental and neurodegenerative diseases using human induced pluripotent stem cells. $J$. Neurogenet. 28:5-29.

Stoll H, Kwon IK, Lim JY. 2014. Material and mechanical factors: new strategy in cellular neurogenesis. Neural Regen. Res. 9:1810-3.

Sun J, Li J, Li C, Yu Y. 2015. Role of bone morphogenetic protein-2 in osteogenic differentiation of mesenchymal stem cells. Mol. Med. Rep. 12:4230-7.

Suter DM, Krause K-H. 2008. Neural commitment of embryonic stem cells: molecules, pathways and potential for cell therapy. J. Pathol. 215:355-68.

Swift J, Ivanovska IL, Buxboim A, Harada T, Dingal PCDP, Pinter J, Pajerowski JD, Spinler KR, Shin J-W, Tewari M, Rehfeldt F, Speicher DW, Discher DE. 2013. Nuclear laminA scales with tissue stiffness and enhances matrix-directed differentiation. Science 341:1240104.

Tabar V, Studer L. 2014. Pluripotent stem cells in regenerative medicine: challenges and recent progress. Nat. Rev. Genet. 15:82-92.

Takahashi K, Yamanaka S. 2006. Induction of pluripotent stem cells from mouse embryonic and adult fibroblast cultures by defined factors. Cell 126:663-76.

Tallawi M, Rai R, Boccaccini AR, Aifantis KE. 2015. Effect of substrate mechanics on cardiomyocyte maturation and growth. Tissue Eng. Part B. Rev. 21:157-65.

Tandon N, Cannizzaro C, Chao P-HG, Maidhof R, Marsano A, Au HTH, Radisic M, VunjakNovakovic G. 2009. Electrical stimulation systems for cardiac tissue engineering. Nat. Protoc. 4:155-73.

Tchao J, Han L, Lin B, Yang L, Tobita K. 2014. Combined biophysical and soluble factor modulation induces cardiomyocyte differentiation from human muscle derived stem cells. Sci. Rep. 4:6614.

Teo BKK, Ankam S, Chan LY, Yim EKFF. 2010. Nanotopography/mechanical induction of stem-cell differentiation. Methods Cell Biol. 98:241-94.

Thrivikraman G, Madras G, Basu B. 2014. Intermittent electrical stimuli for guidance of human mesenchymal stem cell lineage commitment towards neural-like cells on electroconductive substrates. Biomaterials 35:6219-6235.

Trounson A. 2006. The production and directed differentiation of human embryonic stem cells. Endocr. Rev. 27:208-19.

Tse JR, Engler AJ. 2011. Stiffness gradients mimicking in vivo tissue variation regulate mesenchymal stem cell fate. PLoS One 6:e15978.

Uddin SMZ, Qin Y-X. 2013. Enhancement of osteogenic differentiation and proliferation in human mesenchymal stem cells by a modified low intensity ultrasound stimulation under simulated microgravity. PLoS One 8:e73914.

Unadkat H V., Groen N, Doorn J, Fischer B, Barradas AMC, Hulsman M, van de Peppel J, Moroni L, van Leeuwen JP, Reinders MJT, van Blitterswijk CA, de Boer J. 2013. High content imaging in the screening of biomaterial-induced MSC behavior. Biomaterials 34:1498-505.

Unadkat H V, Hulsman M, Cornelissen K, Papenburg BJ, Truckenmüller RK, Carpenter AE, 
Wessling M, Post GF, Uetz M, Reinders MJT, Stamatialis D, van Blitterswijk CA, de Boer J. 2011. An algorithm-based topographical biomaterials library to instruct cell fate. Proc. Natl. Acad. Sci. U. S. A. 108:16565-70.

Unknown. 2011. C-Pace EP culture stimulator for chronic pacing. Milton, Massachusetts: IonOptix.

Vidane AS, Zomer HD, Oliveira BMM, Guimarães CF, Fernandes CB, Perecin F, Silva L a., Miglino M a., Meirelles F V., Ambrósio CE. 2013. Reproductive stem cell differentiation: extracellular matrix, tissue microenvironment, and growth factors direct the mesenchymal stem cell lineage commitment. Reprod. Sci. 20:1137-43.

Villa-Diaz LG, Ross AM, Lahann J, Krebsbach PH. 2013. Concise review: The evolution of human pluripotent stem cell culture: from feeder cells to synthetic coatings. Stem Cells 31:1-7.

Vukicevic S, Kleinman HK, Luyten FP, Roberts AB, Roche NS, Reddi a H. 1992. Identification of multiple active growth factors in basement membrane Matrigel suggests caution in interpretation of cellular activity related to extracellular matrix components. Exp. Cell Res. 202:1-8.

Walters NJ, Gentleman E. 2015. Evolving insights in cell-matrix interactions: elucidating how non-soluble properties of the extracellular niche direct stem cell fate. Acta Biomater. 11:3-16.

Wan LQ, Kang SM, Eng G, Grayson WL, Lu XL, Huo B, Gimble J, Guo XE, Mow VC, Vunjak-Novakovic G. 2010. Geometric control of human stem cell morphology and differentiation. Integr. Biol. (Camb). 2:346-53.

Wang P-Y, Bennetsen DT, Foss M, Thissen H, Kingshott P. 2015a. Response of MG63 osteoblast-like cells to ordered nanotopographies fabricated using colloidal selfassembly and glancing angle deposition. Biointerphases 10:04A306.

Wang P-Y, Bennetsen DT, Foss M, Ameringer T, Thissen H, Kingshott P. 2015b. Modulation of human mesenchymal stem cell behavior on ordered tantalum nanotopographies fabricated using colloidal lithography and glancing angle deposition. ACS Appl. Mater. Interfaces 7:4979-89.

Wang P-Y, Clements LR, Thissen H, Tsai W-B, Voelcker NH. 2015c. Screening rat mesenchymal stem cell attachment and differentiation on surface chemistries using plasma polymer gradients. Acta Biomater. 11:58-67.

Wang P-Y, Clements LR, Thissen H, Hung S-C, Cheng N-C, Tsai W-B, Voelcker NH. 2012a. Screening the attachment and spreading of bone marrow-derived and adiposederived mesenchymal stem cells on porous silicon gradients. RSC Adv. 2:12857.

Wang P-Y, Clements LR, Thissen H, Jane A, Tsai W-B, Voelcker NH. 2012b. Screening mesenchymal stem cell attachment and differentiation on porous silicon gradients. $A d v$. Funct. Mater. 22:3414-3423.

Wang P-Y, Clements LR, Thissen H, Tsai W-B, Voelcker NH. 2013a. High-throughput characterisation of osteogenic differentiation of human mesenchymal stem cells using pore size gradients on porous alumina. Biomater. Sci. 1:924.

Wang P-Y, Li W-T, Yu J, Tsai W-B. 2012c. Modulation of osteogenic, adipogenic and myogenic differentiation of mesenchymal stem cells by submicron grooved topography. 
J. Mater. Sci. Mater. Med. 23:3015-3028.

Wang P-Y, Pingle H, Koegler P, Thissen H, Kingshott P. 2015d. Self-assembled binary colloidal crystal monolayers as cell culture substrates. J. Mater. Chem. B 3:2545-2552.

Wang P-Y, Thissen H, Kingshott P. 2016a. Modulation of human multipotent and pluripotent stem cells using surface nanotopographies and surface-immobilised bioactive signals: a review. Acta Biomater. accepted.

Wang P-Y, Thissen H, Kingshott P. 2016b. Stimulation of early osteochondral differentiation of human mesenchymal stem cells using binary colloidal crystals (BCCs). ACS Appl. Mater. Interfaces 8:4477-88.

Wang P-Y, Thissen H, Tsai W-B. 2012d. The roles of RGD and grooved topography in the adhesion, morphology, and differentiation of $\mathrm{C} 2 \mathrm{C} 12$ skeletal myoblasts. Biotechnol. Bioeng. 109:2104-15.

Wang P-Y, Tsai W-B. 2015. Stem-cell responses to surface nanotopographies. In: . Stem-Cell Nanoeng. Hoboken, NJ: John Wiley \& Sons, Inc, pp. 185-203.

Wang P-Y, Tsai W-B, Voelcker NH. 2012e. Screening of rat mesenchymal stem cell behaviour on polydimethylsiloxane stiffness gradients. Acta Biomater. 8:519-30.

Wang P-Y, Wu T-H, Chao P-HG, Kuo W-H, Wang M-J, Hsu C-C, Tsai W-B. 2013b. Modulation of cell attachment and collagen production of anterior cruciate ligament cells via submicron grooves/ridges structures with different cell affinity. Biotechnol. Bioeng. 110:327-37.

Wang P-Y, Wu T-H, Tsai W-B, Kuo W-H, Wang M-J. 2013c. Grooved PLGA films incorporated with RGD/YIGSR peptides for potential application on skeletal muscle tissue engineering. Colloids Surf. B. Biointerfaces 110:88-95.

Wang P-Y, Yu H-T, Tsai W-B. 2010. Modulation of alignment and differentiation of skeletal myoblasts by submicron ridges/grooves surface structure. Biotechnol. Bioeng. 106:28594.

Wang P-Y, Yu J, Lin J-H, Tsai W-B. 2011. Modulation of alignment, elongation and contraction of cardiomyocytes through a combination of nanotopography and rigidity of substrates. Acta Biomater. 7:3285-93.

Wang Y, Wang D, Guo D. 2016c. MiR-124 promote neurogenic transdifferentiation of adipose derived mesenchymal stromal cells partly through RhoA/ROCK1, but not ROCK2 signaling pathway. Ed. Zoran Ivanovic. PLoS One 11:e0146646.

Wang Y, Peng W, Liu X, Zhu M, Sun T, Peng Q, Zeng Y, Feng B, Zhi W, Weng J, Wang J. 2014. Study of bilineage differentiation of human-bone-marrow-derived mesenchymal stem cells in oxidized sodium alginate/N-succinyl chitosan hydrogels and synergistic effects of RGD modification and low-intensity pulsed ultrasound. Acta Biomater. 10:2518-28.

Wanjare M, Agarwal N, Gerecht S. 2015. Biomechanical strain induces elastin and collagen production in human pluripotent stem cell-derived vascular smooth muscle cells. Am. J. Physiol. Cell Physiol. 309:C271-81.

Wesselschmidt RL, McDonald JW. 2006. Embryonic Stem Cells and Neurogenesis. In: Rao, MS, Carpenter, M, Vemuri, MC, editors. Neural Dev. Stem Cells. Totowa, NJ: Humana Press, pp. 299-341. 
Wilner JI. 2010. The Effects of Photostimulation on Stem Cell Proliferation and Differentiation; Tufts University.

Wittenbrink I, Hausmann A, Schickle K, Lauria I, Davtalab R, Foss M, Keller A, Fischer H. 2015. Low-aspect ratio nanopatterns on bioinert alumina influence the response and morphology of osteoblast-like cells. Biomaterials 62:58-65.

Xu T, Zhang M, Laurent T, Xie M, Ding S. 2013. Concise review: chemical approaches for modulating lineage-specific stem cells and progenitors. Stem Cells Transl. Med. 2:35561.

Yamada R, Hattori K, Tachikawa S, Tagaya M, Sasaki T, Sugiura S, Kanamori T, Ohnuma K. 2014. Control of adhesion of human induced pluripotent stem cells to plasmapatterned polydimethylsiloxane coated with vitronectin and $\gamma$-globulin. J. Biosci. Bioeng. 118:315-22.

Yan P, Nagasawa A, Uosaki H, Sugimoto A, Yamamizu K, Teranishi M, Matsuda H, Matsuoka S, Ikeda T, Komeda M, Sakata R, Yamashita JK. 2009. Cyclosporin-A potently induces highly cardiogenic progenitors from embryonic stem cells. Biochem. Biophys. Res. Commun. 379:115-20.

Yang K, Jung K, Ko E, Kim J, Park KI, Kim J, Cho S-W. 2013. Nanotopographical manipulation of focal adhesion formation for enhanced differentiation of human neural stem cells. ACS Appl. Mater. Interfaces 5:10529-40.

Yang K, Park H, Han S, Lee J, Ko E, Kim J, Lee JS, Yu JH, Song KY, Cheong E, Cho S-R, Chung S, Cho S. 2015. Recapitulation of in vivo-like paracrine signals of human mesenchymal stem cells for functional neuronal differentiation of human neural stem cells in a 3D microfluidic system. Biomaterials 63:177-88.

Yang L, Soonpaa MH, Adler ED, Roepke TK, Kattman SJ, Kennedy M, Henckaerts E, Bonham K, Abbott GW, Linden RM, Field LJ, Keller GM. 2008. Human cardiovascular progenitor cells develop from a KDR+ embryonic-stem-cell-derived population. Nature 453:524-8.

Yao L, Pandit A, Yao S, McCaig CD. 2011. Electric field-guided neuron migration: a novel approach in neurogenesis. Tissue Eng. Part B. Rev. 17:143-53.

Yoshida Y, Yamanaka S. 2010. Recent stem cell advances: induced pluripotent stem cells for disease modeling and stem cell-based regeneration. Circulation 122:80-7.

Young DA, Choi YS, Engler AJ, Christman KL. 2013. Stimulation of adipogenesis of adult adipose-derived stem cells using substrates that mimic the stiffness of adipose tissue. Biomaterials 34:8581-8.

Zanini C, Bruno S, Mandili G, Baci D, Cerutti F, Cenacchi G, Izzi L, Camussi G, Forni M. 2011. Differentiation of mesenchymal stem cells derived from pancreatic islets and bone marrow into islet-like cell phenotype. PLoS One 6:e28175.

Zhang J, Wilson GF, Soerens AG, Koonce CH, Yu J, Palecek SP, Thomson J a., Kamp TJ. 2009. Functional cardiomyocytes derived from human induced pluripotent stem cells. Circ. Res. 104:e30-41.

Zhang N, Kohn DH. 2012. Using polymeric materials to control stem cell behavior for tissue regeneration. Birth Defects Res. Part C Embryo Today Rev. 96:63-81.

Zhang Y, Liang X, Lian Q, Tse H-F. 2013. Perspective and challenges of mesenchymal stem 
cells for cardiovascular regeneration. Expert Rev. Cardiovasc. Ther. 11:505-17.

Zhang Y, Lukacova V, Reindl K, Balaz S. 2006. Quantitative characterization of binding of small molecules to extracellular matrix. J. Biochem. Biophys. Methods 67:107-22.

Zimmermann W-H. 2013. Biomechanical regulation of in vitro cardiogenesis for tissueengineered heart repair. Stem Cell Res. Ther. 4:137.

Table 1. Biophysical stimulation and its effects on stem cell behaviour or cell phenotype

\begin{tabular}{|c|c|c|c|c|}
\hline STEM CELL & LINEAGE & BIOPHYSICAL STIMULATION & EFFECT & REF. \\
\hline hiPSC & cardiomyocytes & $\begin{array}{l}\text { Electrical stimulation ( } 2 \mathrm{~Hz} \text { for } 1 \\
\text { week, then } 1.5 \mathrm{~Hz} \text { after) }\end{array}$ & $\begin{array}{l}\text { Cell alignment. Elongated } \\
\text { cell morphology. Greater } \\
\text { contractile force. } \\
\text { Organised cross-striation. }\end{array}$ & $\begin{array}{l}\text { (Hirt et al., } \\
\text { 2014) }\end{array}$ \\
\hline hiPSC & cardiomyocytes & $4 \mu \mathrm{m} / 10 \mu \mathrm{m}(\mathrm{w} / \mathrm{d})$ microgrooves & $\begin{array}{l}\text { Cell alignment. Elongated } \\
\text { cell morphology. } \\
\text { Organised cross-striation. } \\
\text { Organised sarcoplasmic } \\
\text { reticulum. }\end{array}$ & $\begin{array}{l}\text { (Rao et al., } \\
\text { 2013) }\end{array}$ \\
\hline hiPSC & $\begin{array}{l}\text { neural stem } \\
\text { cells }\end{array}$ & $\begin{array}{l}\text { Low-intensity ultrasound (500 } \mathrm{mW} \\
\left.\qquad \mathrm{cm}^{-2}\right)\end{array}$ & $\begin{array}{l}\text { Proliferation. } \\
\text { Differentiation. }\end{array}$ & $\begin{array}{l}\text { (Lv et al., } \\
\text { 2013) }\end{array}$ \\
\hline hESC & neural cells & Nanogrooves $(350 \mathrm{~nm} / 500 \mathrm{~nm} \mathrm{w} / \mathrm{d})$ & Differentiation. & $\begin{array}{l}\text { (Lee et al., } \\
\text { 2010) }\end{array}$ \\
\hline hESC & neural cells & Nanofibrils & Differentiation. & $\begin{array}{l}\text { (Sridharan et } \\
\text { al., 2009) }\end{array}$ \\
\hline hESC & - & $\begin{array}{l}\text { Cyclic stretching ( } 10 \% \text { strain, } 10 \text { or } \\
30 \text { cycles } / \mathrm{min})\end{array}$ & $\begin{array}{l}\text { Stem cell phenotype } \\
\text { (proliferation, }\end{array}$ & $\begin{array}{l}\text { (Saha et al., } \\
\text { 2006) }\end{array}$ \\
\hline hESC & neural stem cell & Electrical field $(16 \mathrm{mV} / \mathrm{mm})$ & Migration. & $\begin{array}{l}\text { (Feng et al., } \\
\text { 2012) }\end{array}$ \\
\hline $\mathrm{hESC}$ & - & Shear stress $<8$ dynes $/ \mathrm{cm}^{2}$ & $\begin{array}{l}\text { Stem cell phenotype } \\
\text { (proliferation, } \\
\text { pluripotency). }\end{array}$ & $\begin{array}{c}\text { (Geuss and } \\
\text { Suggs, 2013) }\end{array}$ \\
\hline hiPSC, hESC & $\begin{array}{c}\text { vascular } \\
\text { smooth muscle } \\
\text { cells }\end{array}$ & $\begin{array}{l}\text { Uniaxial tensile strain ( } 7 \% \\
\text { elongation), } 24 \text { hours }\end{array}$ & $\begin{array}{l}\text { Cell alignment } \\
\text { perpendicular to direction } \\
\text { of strain. Increased ECM } \\
\text { gene expression. }\end{array}$ & $\begin{array}{l}\text { (Wanjare et } \\
\text { al., 2015) }\end{array}$ \\
\hline hiPSC, hESC & $\begin{array}{l}\text { vascular } \\
\text { smooth muscle } \\
\text { cells }\end{array}$ & $\begin{array}{c}\text { Circumferential tensile strain ( } 7 \% \\
\text { elongation), } 6 \text { days }\end{array}$ & $\begin{array}{l}\text { Increased collagen III and } \\
\text { elastin expression. }\end{array}$ & $\begin{array}{l}\text { (Wanjare et } \\
\text { al., 2015) }\end{array}$ \\
\hline hMSC & $\begin{array}{l}\text { osteoblasts, } \\
\text { fibroblasts }\end{array}$ & $\begin{array}{c}\text { Cyclic uniaxial tension (10\% strain, } \\
0.1 \mathrm{~Hz} \text { frequency) }\end{array}$ & Increased gene expression. & $\begin{array}{l}\text { (Haudenschild } \\
\text { et al., 2009) }\end{array}$ \\
\hline hMSC & chondrocytes & $\begin{array}{c}\text { Cyclic compression ( } 5 \% \text { strain, } 0.1 \\
\text { Hz frequency) }\end{array}$ & Increased gene expression. & $\begin{array}{l}\text { (Haudenschild } \\
\text { et al., 2009) }\end{array}$ \\
\hline hMSC & $\begin{array}{l}\text { osteoblasts, } \\
\text { apidocytes }\end{array}$ & $\begin{array}{l}\text { Oscillatory shear strain }(0.5 \pm 4 \\
\left.\mathrm{dyn} / \mathrm{cm}^{2}\right), \text { up to } 24 \text { hours }\end{array}$ & Differentiation. & $\begin{array}{l}\text { (Kuo et al., } \\
\text { 2015) }\end{array}$ \\
\hline hMSC & osteoblasts & $\begin{array}{c}\text { Nanotopography (120 nm pits, } 300 \\
\text { nm square lattice pacing, } 50 \mathrm{~nm} \\
\text { offset) }\end{array}$ & Differentiation. & $\begin{array}{l}\text { (Dalby et al., } \\
\text { 2007) }\end{array}$ \\
\hline hMSC & osteoblasts & $\begin{array}{l}\text { Low frequency electromagnetic field } \\
\qquad(30-45 \mathrm{~Hz}, 1 \mathrm{mT})\end{array}$ & Differentiation. & $\begin{array}{l}\text { (Kang et al., } \\
\text { 2013b) }\end{array}$ \\
\hline hMSC & osteoblasts & $\begin{array}{l}\text { Low frequency electromagnetic field } \\
\qquad(7.5 \mathrm{~Hz}, 1 \mathrm{mT})\end{array}$ & Multipotency. & $\begin{array}{l}\text { (Kang et al., } \\
\text { 2013b) }\end{array}$ \\
\hline hMSC & osteoblasts & $1.5 \mathrm{MHz}$ ultrasound & Differentiation. & $\begin{array}{l}\text { (Kang et al., } \\
\text { 2013a) }\end{array}$ \\
\hline hMSC & neurons & $\begin{array}{l}\text { Low frequency electromagnetic field } \\
\text { (sinusoidal, } 1 \mathrm{mT}, 50 \mathrm{~Hz} \text { ) }\end{array}$ & $\begin{array}{l}\text { Differentiation. Decreased } \\
\text { proliferation. }\end{array}$ & $\begin{array}{l}\text { (Cho et al., } \\
\text { 2012) }\end{array}$ \\
\hline
\end{tabular}




\begin{tabular}{|c|c|c|c|c|}
\hline hMSC & neurons & $\begin{array}{l}\text { Electrical field (100 mV/min), } 10 \\
\text { min/day }\end{array}$ & $\begin{array}{l}\text { Neuron-like morphology. } \\
\text { Increased gene expression. }\end{array}$ & $\begin{array}{l}\text { (Thrivikraman } \\
\text { et al., 2014) }\end{array}$ \\
\hline hMSC & - & Blue light (455 nm or $470 \mathrm{~nm})$ & Decreased proliferation. & $\begin{array}{l}\text { (Wilner, } \\
\text { 2010) }\end{array}$ \\
\hline hMSC & - & Microscale ordered BCC monolayers & Multipotency. & $\begin{array}{l}\text { (Wang et al., } \\
\text { 2015d) }\end{array}$ \\
\hline hMSC & - & $\begin{array}{l}\text { Ordered nanotopography (120 nm } \\
\text { pits, } 300 \mathrm{~nm} \text { square lattice spacing) }\end{array}$ & Multipotency. & $\begin{array}{l}\text { (McMurray et } \\
\text { al., 2011) }\end{array}$ \\
\hline $\begin{array}{l}\text { human neural } \\
\text { stem cells }\end{array}$ & neurons & $\begin{array}{l}\text { Reduced graphene oxide nano-mesh } \\
\text { substrate; near-infrared laser light } \\
(808 \mathrm{~nm})\end{array}$ & Differentiation. & $\begin{array}{l}\text { (Akhavan et } \\
\text { al., 2015) }\end{array}$ \\
\hline $\begin{array}{l}\text { human neural } \\
\text { stem cells }\end{array}$ & neurons & Electrical field $(1 \mathrm{~V} / \mathrm{cm})$ & $\begin{array}{l}\text { Elongated morphology. } \\
\text { Differentiation. }\end{array}$ & $\begin{array}{l}\text { (Pires et al., } \\
\text { 2015) }\end{array}$ \\
\hline $\begin{array}{l}\text { human } \\
\text { epithelial } \\
\text { stem cells }\end{array}$ & - & Helium-neon laser light (632.8 nm) & $\begin{array}{l}\text { Proliferation. Cell } \\
\text { migration. }\end{array}$ & $\begin{array}{l}\text { (Liao et al., } \\
\text { 2014) }\end{array}$ \\
\hline
\end{tabular}

Abbreviations: hESC, human embryonic stem cells; hiPSC, human induced pluripotent stem cells; hPSC, human pluripotent stem cells; hMSC, human mesenchymal stem cells.

Table 2. Key components for biochemical induction of directed stem cell differentiation.

\begin{tabular}{|c|c|c|c|}
\hline STEM CELL & LINEAGE & KEY COMPONENTS OF INDUCTION MEDIA & REF. \\
\hline hPSC & $\begin{array}{l}\text { Cardiomyoc } \\
\text { ytes }\end{array}$ & activin-A, BMP-4, Dkk-1, VEGF, bFGF & $\begin{array}{l}\text { (Hartman et al., } \\
\text { 2015; Mummery et } \\
\text { al., 2012) }\end{array}$ \\
\hline hPSC & $\begin{array}{l}\text { Cardiomyoc } \\
\text { ytes }\end{array}$ & CHIR99021, DMH1 & (Aguilar et al., 2015) \\
\hline hPSC & Neural cells & LDN, CHIR99021, Noggin, SB431542 & $\begin{array}{l}\text { (Chambers et al., } \\
\text { 2016) }\end{array}$ \\
\hline hPSC & Astrocytes & retinoic acid, FGF-8 & (Krencik et al., 2011) \\
\hline hPSC & $\begin{array}{l}\text { Pancreatic } \\
\text { cells }\end{array}$ & Activin A, FGFs, retinoic acid, LDN, SANT & $\begin{array}{c}\text { (Pagliuca et al., } \\
\text { 2014; Rezania et al., } \\
\text { 2014) }\end{array}$ \\
\hline hiPSC & Hepatocytes & DEX, activin-A, bFGF, BMP-4, HGF, OSM & $\begin{array}{c}\text { (Mallanna and } \\
\text { Duncan, 2013; } \\
\text { Schwartz et al., } \\
\text { 2014) }\end{array}$ \\
\hline hESC & $\begin{array}{l}\text { Endothelial } \\
\text { cells }\end{array}$ & hydrocortisone, human EGF, bFGF, heparin & (Kane et al., 2010) \\
\hline hESC & $\begin{array}{l}\text { Pancreatic } \\
\text { cells }\end{array}$ & $\begin{array}{c}\text { activin, Wnt, FGF-10, CYC, retinoic acid, DAPT, Ex4, IGF-1, } \\
\text { HGF }\end{array}$ & $\begin{array}{l}\text { (D’Amour et al., } \\
\text { 2006) }\end{array}$ \\
\hline hESC & $\begin{array}{l}\text { Pancreatic } \\
\text { cells }\end{array}$ & activin $\mathrm{A}, \mathrm{Wnt}, \mathrm{KGF}, \mathrm{CYC}$ & (Kroon et al., 2008) \\
\hline hESC & $\begin{array}{l}\text { Neural stem } \\
\text { cells }\end{array}$ & retinoic acid & $\begin{array}{l}\text { (Wesselschmidt and } \\
\text { McDonald, 2006) }\end{array}$ \\
\hline hESC & Astrocytes & retinoic acid, SHH, EGF, bFGF, CNTF, 10\% FBS & (Krencik et al., 2011) \\
\hline hESC & $\begin{array}{l}\text { Oligodendro } \\
\text { cytes }\end{array}$ & retinoic acid, $\mathrm{SHH}, \mathrm{bFGF}$ & (Hu et al., 2009) \\
\hline hESC & Neurons & retinoic acid, bFGF, EGF (and SHH for motor neurons) & $\begin{array}{l}\text { (Robertson et al., } \\
\text { 2008) }\end{array}$ \\
\hline hESC & $\begin{array}{l}\text { Dopaminerg } \\
\text { ic neurons }\end{array}$ & SHH, FGF-8, ascorbic acid & $\begin{array}{l}\text { (Robertson et al., } \\
\text { 2008) }\end{array}$ \\
\hline hESC & Retinal cells & leftyA, activin, Dkk-1, serum & $\begin{array}{l}\text { (Robertson et al., } \\
\text { 2008) }\end{array}$ \\
\hline hMSC & Osteocytes & DEX, b-glycerophosphate, ascorbic acid, $10 \%$ FBS & $\begin{array}{l}\text { (Pittenger et al., } \\
\text { 1999) }\end{array}$ \\
\hline hMSC & Adipocytes & $\begin{array}{l}\text { DEX, indomethacin, insulin, 3-isobutyl-L-methylxanthine, } 10 \% \\
\text { FBS }\end{array}$ & $\begin{array}{l}\text { (Narvaez et al., } \\
2013 \text { ) }\end{array}$ \\
\hline
\end{tabular}




\begin{tabular}{cccc} 
hMSC & $\begin{array}{c}\text { Chondrocyt } \\
\text { es } \\
\text { Epithelial } \\
\text { cells } \\
\text { hMSC }\end{array}$ & DEX, TGF, BMP-2, glucose, FBS & $\begin{array}{c}\text { (Hadjizadeh and } \\
\text { Doillon, 2010) } \\
\text { (Brzoska et al., }\end{array}$ \\
hMSC & all-trans retinoic acid, 10\% FBS, DMSO & 2005) \\
hMSC & Endoderm & DMEM, 2\% DMSO, BHA, potassium chloride, forskolin, hydro- & (Qian and Saltzman, \\
hMSC & $\begin{array}{c}\text { Pancreatic } \\
\text { cells }\end{array}$ & retinoic acid, activin, GLPI-1, EGF, FGF, platelet lysate, beta- & 2004) \\
& (Zanini et al., 2011) \\
\hline
\end{tabular}

Abbreviations: BHA, butylated hydroxyanisole; BMP, bone morphogenetic protein; CHIR99021, small molecule; CNTF, ciliary neurotrophic factor; CYC, KAAD-cyclopamine; DAPT, $\gamma$-secretase inhibitor; DEX, dexamethasone; Dkk-1, Dickkopf-1; DMH1, bone morphogenetic protein signalling inhibitor; DMSO, dimethyl sulfoxide; EGF, epidermal growth factor; Ex4, exendin-4; FBS, foetal bovine serum; FGF, fibroblast growth factor; bFGF (aka FGF2), basic fibroblast growth factor; GLPI-1, glucagon-like peptide 1; hESC, human embryonic stem cells; HGF, hepatocyte growth factor; hiPSC, human induced pluripotent stem cells; hMSC, human mesenchymal stem cells; hPSC, human pluripotent stem cells; IGF, insulin-like growth factor; KGF, keratinocyte growth factor; LDN, selective BMP inhibitor LDN-193189; mESC, mouse embryonic stem cells; SB431542, Lefty/Activin/TGF $\beta$ pathway inhibitor; OSM, oncostatin M; SHH, sonic hedgehog; VEGF, vascular endothelial growth factor.

Table 3. Effects of combined biochemical and biophysical stimulation on stem cells.

\begin{tabular}{|c|c|c|c|c|c|}
\hline $\begin{array}{l}\text { STEM } \\
\text { CELLS }\end{array}$ & LINEAGE & $\begin{array}{c}\text { CHEMICAL } \\
\text { STIMULATION }\end{array}$ & $\begin{array}{c}\text { PHYSICAL } \\
\text { STIMULATION }\end{array}$ & EFFECT & REF. \\
\hline hESC & cardiomyocytes & $\begin{array}{l}\text { IWP4, Gsk3 } \\
\text { inhibitor }\end{array}$ & $\begin{array}{l}\text { Substrate stiffness } \\
(50 \mathrm{kPa})\end{array}$ & Differentiation & $\begin{array}{l}\text { (Hazeltine } \\
\text { et al., } \\
\text { 2014) }\end{array}$ \\
\hline hESC & cardiomyocytes & $\begin{array}{c}\text { p38-MAPK } \\
\text { inhibitor, } \\
\text { transferrin, sodium } \\
\text { selenite, 2- } \\
\text { mercaptoethanol }\end{array}$ & Electrical stimulation & $\begin{array}{l}\text { Cell alignment. Elongated cell } \\
\text { morphology. Increased } \\
\text { cardiac-specific gene } \\
\text { expression. Organised } \\
\text { cytoskeleton. Improved } \mathrm{Ca}^{2+} \\
\text { cycling. }\end{array}$ & $\begin{array}{l}\text { (Chan et } \\
\text { al., 2013) }\end{array}$ \\
\hline hMSC & myocytes & $\begin{array}{l}\text { Myogenic induction } \\
\text { media }\end{array}$ & $\begin{array}{l}\text { Muscle-like matrix } \\
\text { stiffness }\end{array}$ & Differentiation & $\begin{array}{l}\text { (Engler et } \\
\text { al., 2006) }\end{array}$ \\
\hline hMSC & cardiomyocytes & $\begin{array}{l}\text { BMP-4, lithium } \\
\text { chloride, IWR-1, } \\
\text { microRNA-206 } \\
\text { inhibitor }\end{array}$ & $\begin{array}{l}\text { Aggregation, 3D } \\
\text { culture }\end{array}$ & Differentiation & $\begin{array}{l}\text { (Tchao et } \\
\text { al., 2014) }\end{array}$ \\
\hline hMSC & neural cells & $\begin{array}{c}\text { Neurogenic } \\
\text { induction media }\end{array}$ & $\begin{array}{l}\text { Brain-like (soft) } \\
\text { matrix stiffness }\end{array}$ & Differentiation & $\begin{array}{l}\text { (Engler et } \\
\text { al., 2006) }\end{array}$ \\
\hline hMSC & osteoblasts & $\begin{array}{c}\text { Osteogenic } \\
\text { induction media }\end{array}$ & $\begin{array}{l}\text { Collagenous bone-like } \\
\text { (rigid) matrix stiffness }\end{array}$ & Differentiation & $\begin{array}{l}\text { (Engler et } \\
\text { al., 2006) }\end{array}$ \\
\hline hMSC & osteoblasts & $\begin{array}{c}\text { Osteogenic } \\
\text { induction media }\end{array}$ & $\begin{array}{c}100 \mathrm{~nm} \text { or } 200 \mathrm{~nm} \\
\text { particle features, } \\
\text { hexagonal } \\
\text { arrangement }\end{array}$ & $\begin{array}{c}\text { Increased alkaline } \\
\text { phosphatase activity and } \\
\text { osteogenic ECM deposition. } \\
\text { Inhibited cell spreading and } \\
\text { focal adhesion formation. }\end{array}$ & $\begin{array}{l}\text { (Wang et } \\
\text { al., 2015b) }\end{array}$ \\
\hline hMSC & osteoblasts & $\begin{array}{l}\text { Fibronectin; mixed } \\
\text { osteogenic/adipogen } \\
\text { ic induction media. }\end{array}$ & $\begin{array}{l}\text { Sharp-edged star } \\
\text { patterning }\end{array}$ & Differentiation & $\begin{array}{l}\text { (Kilian et } \\
\text { al., 2010) }\end{array}$ \\
\hline hMSC & osteoblasts & $\begin{array}{c}10 \% \text { FBS, DEX, } \\
\text { ascorbic acid 2- } \\
\text { phosphate, } \beta- \\
\text { glycerophosphate }\end{array}$ & $\begin{array}{l}\text { Blue light }(455 \mathrm{~nm} \text { or } \\
\quad 470 \mathrm{~nm})\end{array}$ & Multipotency & $\begin{array}{l}\text { (Wilner, } \\
\text { 2010) }\end{array}$ \\
\hline
\end{tabular}




\begin{tabular}{|c|c|c|c|c|c|}
\hline hMSC & osteoblasts & $\begin{array}{l}10 \% \text { FBS, DEX, } \\
\text { ascorbic acid 2- } \\
\text { phosphate, } \beta- \\
\text { glycerophosphate }\end{array}$ & Red light $(656 \mathrm{~nm})$ & Differentiation & $\begin{array}{l}\text { (Wilner, } \\
\text { 2010) }\end{array}$ \\
\hline hMSC & chondrocytes & $\begin{array}{l}\text { Chondrogenic } \\
\text { induction media } \\
\text { with TGF } \beta 3\end{array}$ & $5 \mathrm{MHz}$ ultrasound & Differentiation & $\begin{array}{l}\text { (Guha } \\
\text { Thakurta et } \\
\text { al., 2015) }\end{array}$ \\
\hline hMSC & adipocytes & $\begin{array}{c}\text { 10\% FBS, DEX, } \\
\text { insulin, } \\
\text { indomethacin, } \\
\text { isobutylmethyl } \\
\text { xanthine }\end{array}$ & $\begin{array}{l}\text { Native-like (adipose } \\
\text { tissue-like) matrix } \\
\text { stiffness }\end{array}$ & Differentiation & $\begin{array}{l}\text { (Young et } \\
\text { al., 2013) }\end{array}$ \\
\hline hMSC & adipocytes & $\begin{array}{l}\text { Fibronectin; mixed } \\
\text { osteogenic/adipogen } \\
\text { ic induction media. }\end{array}$ & $\begin{array}{l}\text { Soft-edged star } \\
\text { patterning }\end{array}$ & Differentiation & $\begin{array}{l}\text { (Kilian et } \\
\text { al., 2010) }\end{array}$ \\
\hline hMSC & $\begin{array}{l}\text { osteoblasts, } \\
\text { endothelium }\end{array}$ & $\begin{array}{l}\text { RGD-grafted } \\
\text { oxidised sodium } \\
\text { alginate/N-succinyl } \\
\text { chitosan hydrogel }\end{array}$ & $\begin{array}{c}\text { Low-intensity pulsed } \\
\text { ultrasound }\end{array}$ & Differentiation & $\begin{array}{l}\text { (Wang et } \\
\text { al., 2014) }\end{array}$ \\
\hline
\end{tabular}

Abbreviations: BMP, bone morphogenetic protein; DEX, dexamethasone; FBS, foetal bovine serum; GSK, glycogen synthase kinase; hESC, human embryonic stem cells; hiPSC, human induced pluripotent stem cells; hMSC, human mesenchymal stem cells; hPSC, human pluripotent stem cells; IWP, inhibitor of Wnt pathway; IWR, inhibitor of Wnt response; p38MAPK, p38 mitogen-activated protein kinase. 
Topography Normal media

$$
\square+09
$$
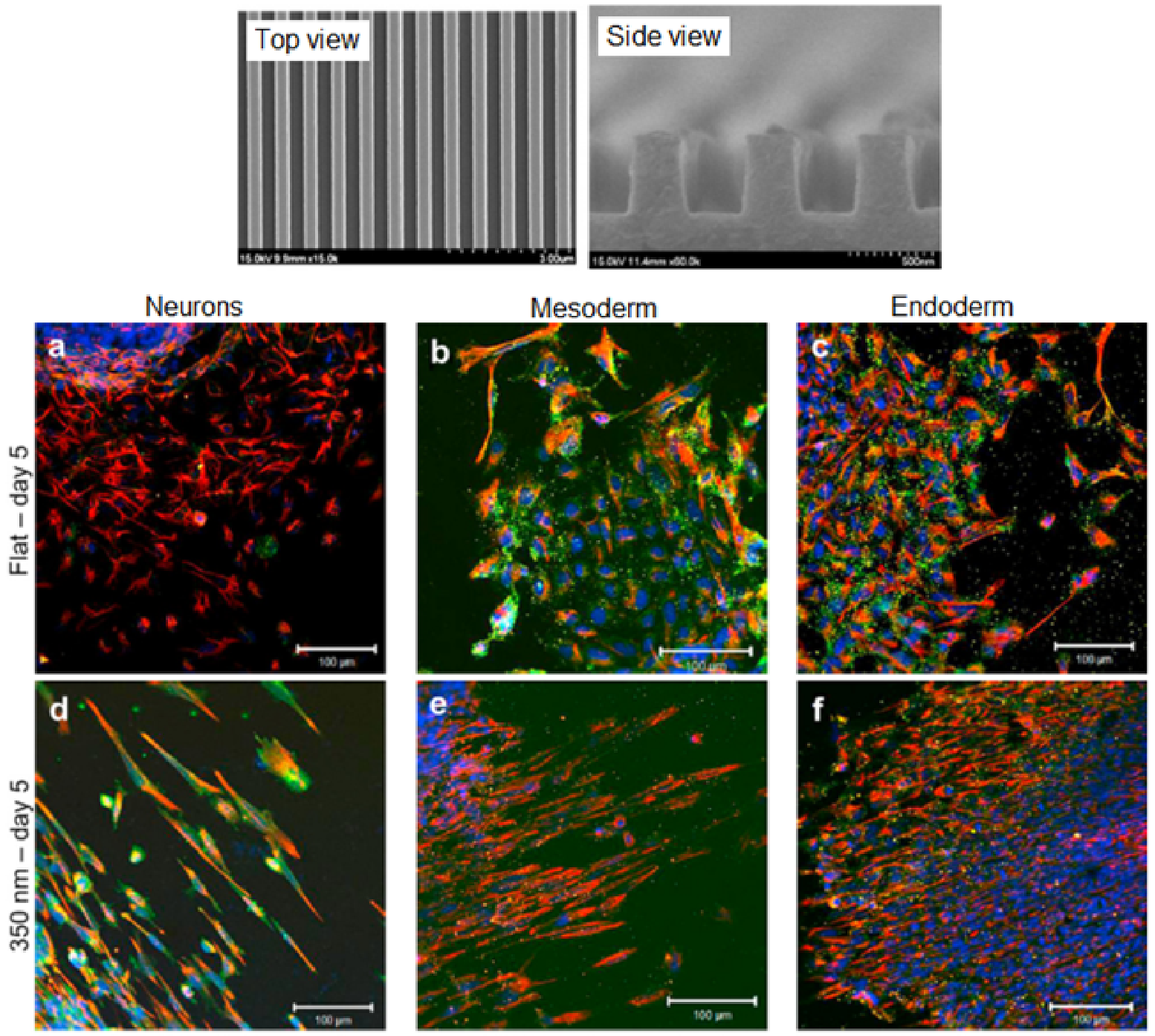

DAPI/Tuj1/Nestin

DAPI/Brachyury/Nestin

DAPI/Pdx $1 /$ Nestin

Figure 1 . 


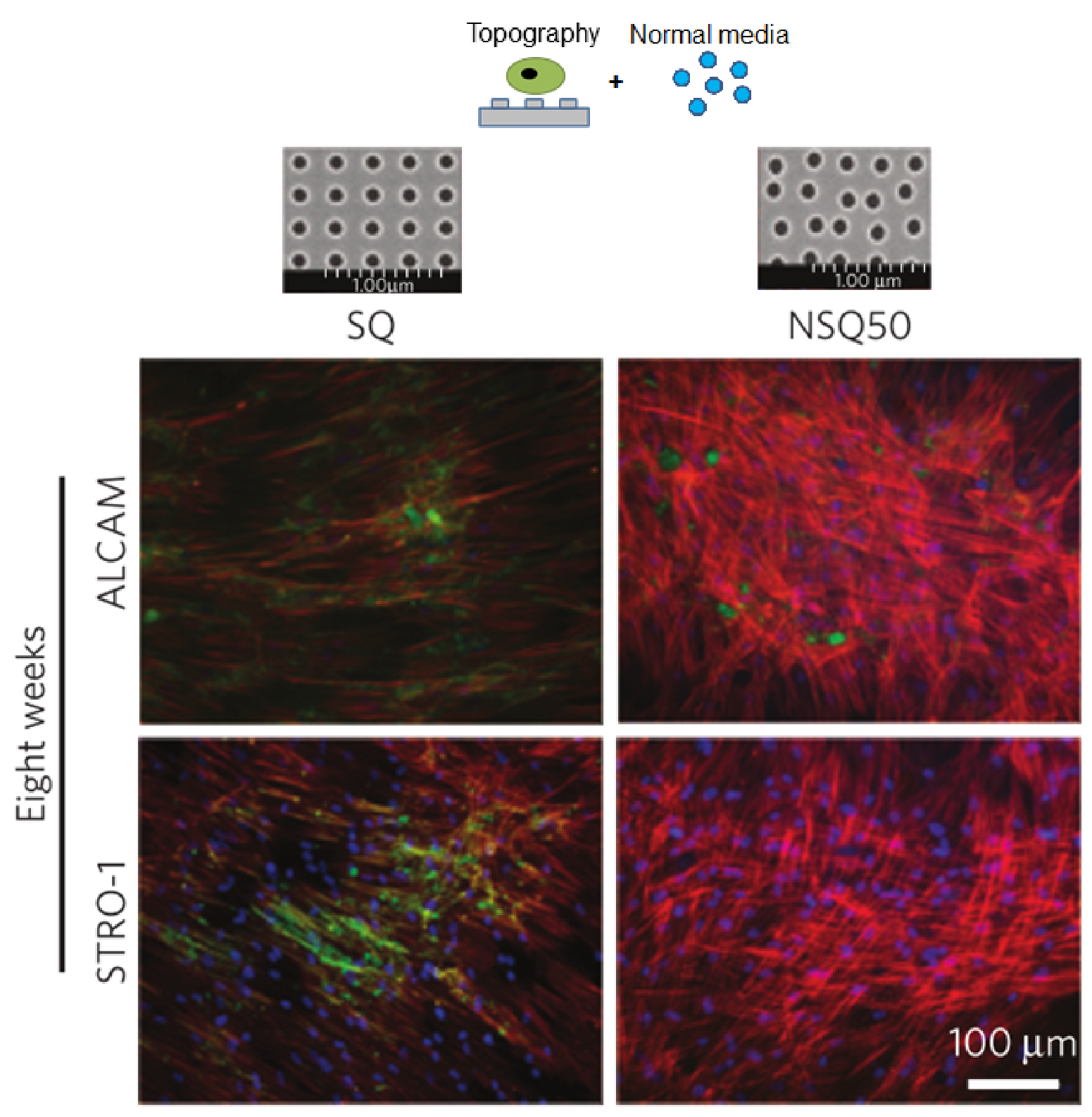

Figure 2 . 
Stiffness Normal media

$$
C+\%
$$

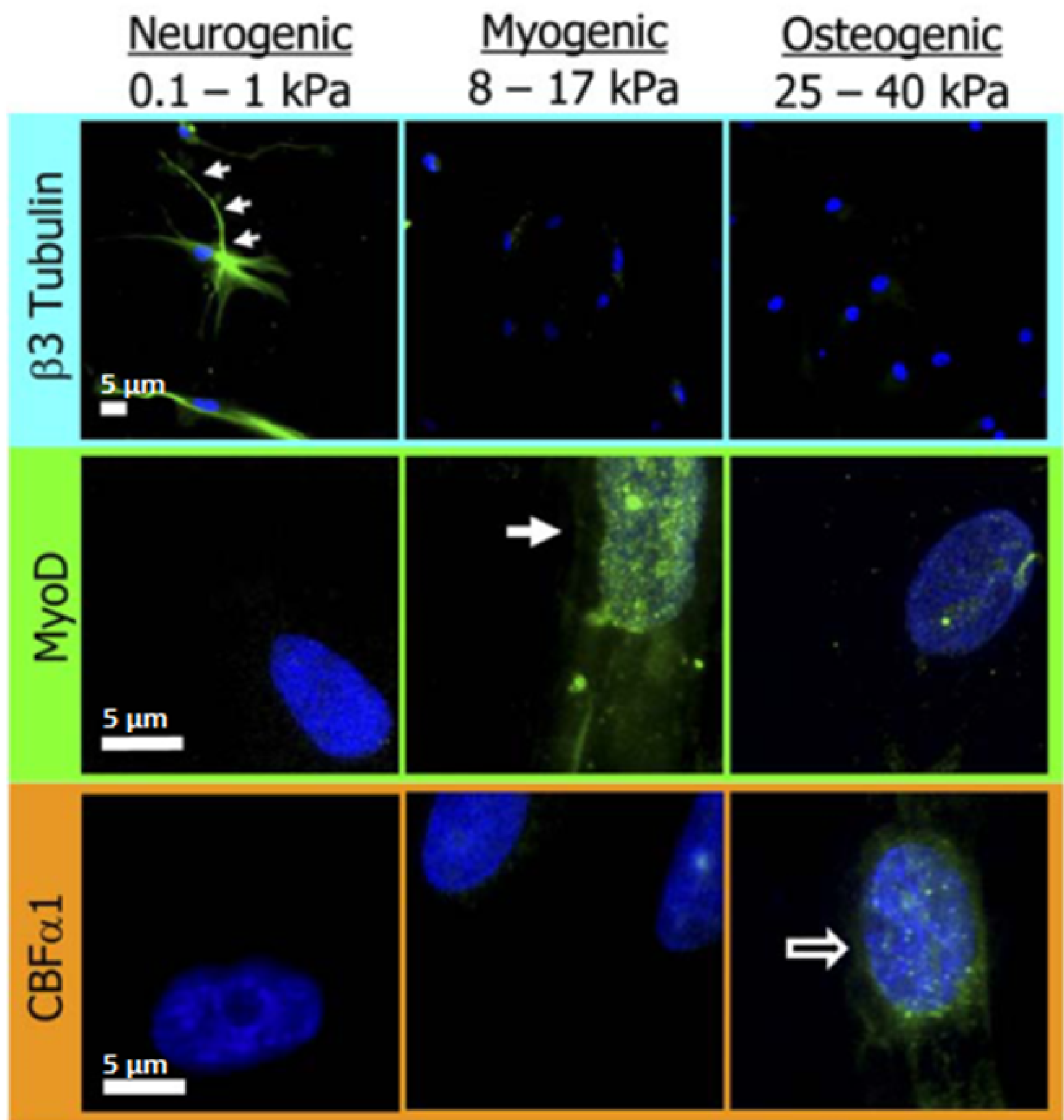

Figure 3 . 


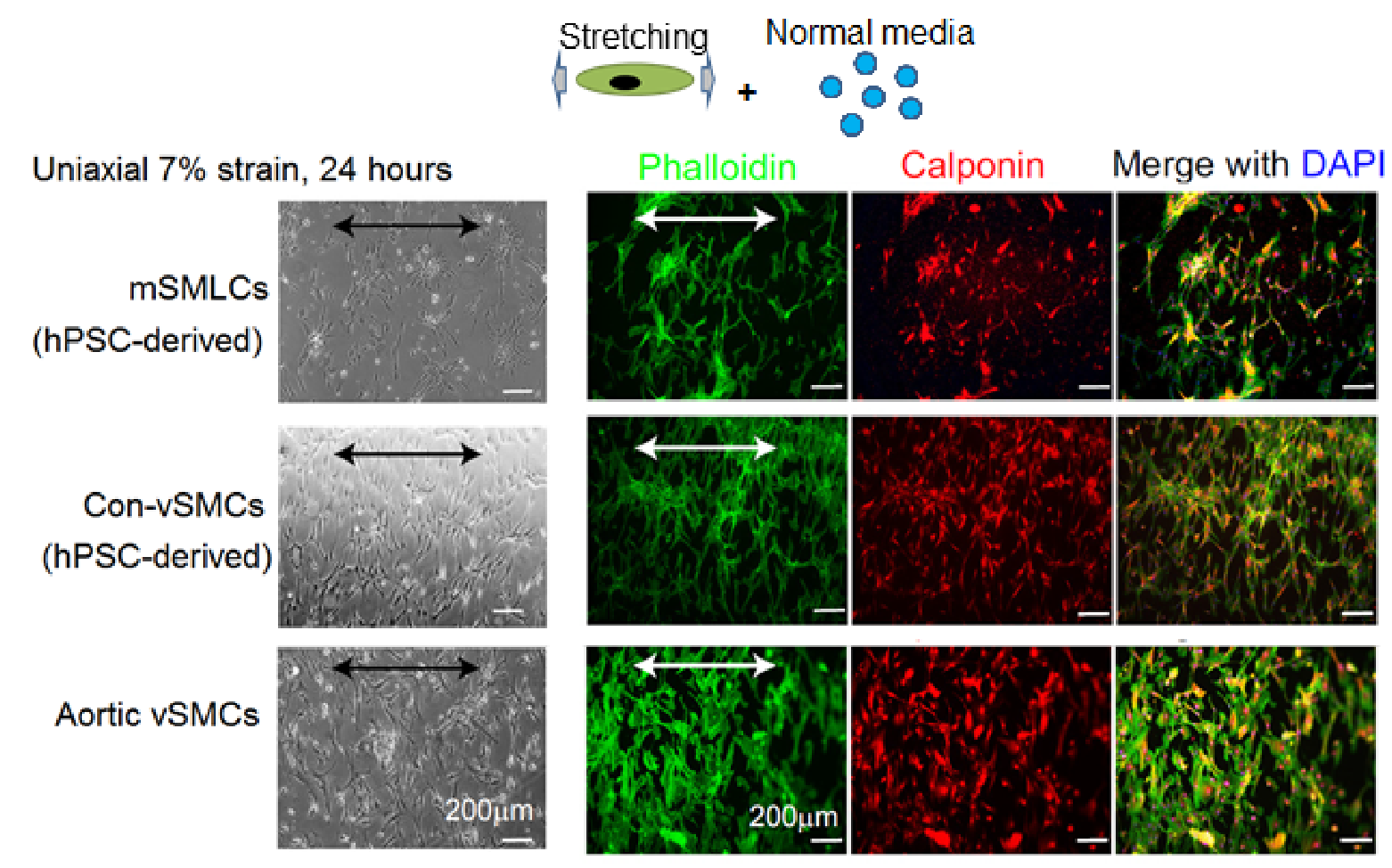

Figure 4 . 

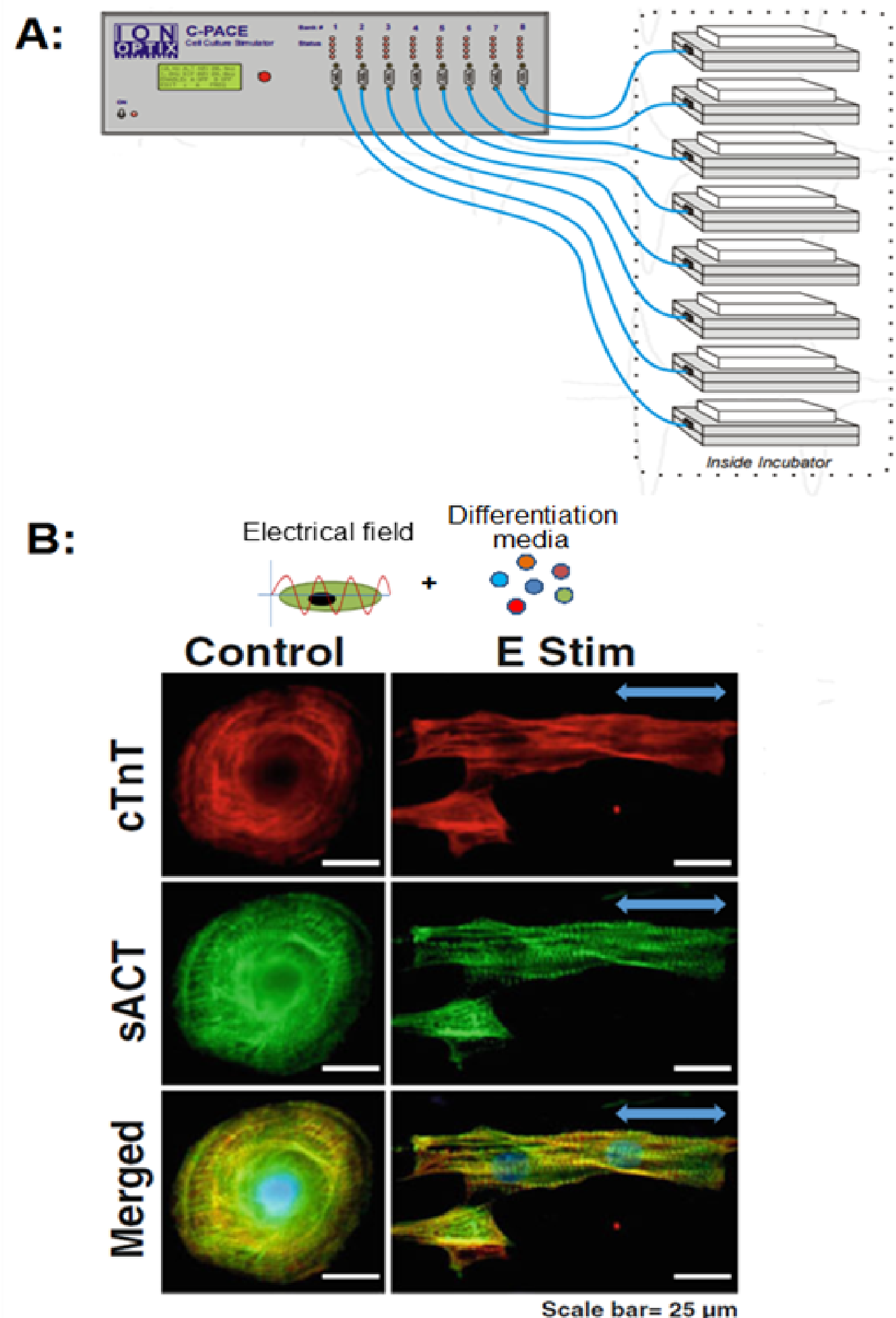

Figure 5 . 


\section{University Library}

\section{- M M N E R VA A gateway to Melbourne's research publications}

Minerva Access is the Institutional Repository of The University of Melbourne

Author/s:

Ding, S;Kingshott, P;Thissen, H;Pera, M;Wang, P-Y

Title:

Modulation of human mesenchymal and pluripotent stem cell behavior using biophysical and biochemical cues: A review

Date:

2017-02-01

Citation:

Ding, S., Kingshott, P., Thissen, H., Pera, M. \& Wang, P. -Y. (2017). Modulation of human mesenchymal and pluripotent stem cell behavior using biophysical and biochemical cues: A review. BIOTECHNOLOGY AND BIOENGINEERING, 114 (2), pp.260-280. https:// doi.org/10.1002/bit.26075.

Persistent Link:

http://hdl.handle.net/11343/291685 